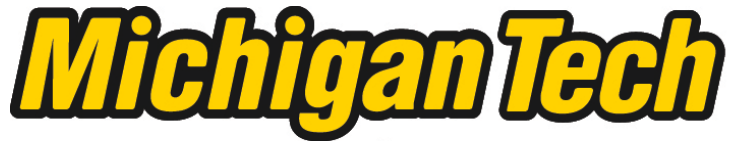 \\ Michigan Technological University Create the Future Digital Commons @ Michigan Tech
}

2005

\section{Vegetation and hydrologic influences on carbon and nitrogen in subsurface water of a forested riparian wetland}

Emily B. W. Calhoon

Michigan Technological University

Follow this and additional works at: https://digitalcommons.mtu.edu/etds

Part of the Forest Sciences Commons

Copyright 2005 Emily B. W. Calhoon

\section{Recommended Citation}

Calhoon, Emily B. W., "Vegetation and hydrologic influences on carbon and nitrogen in subsurface water of a forested riparian wetland", Master's Thesis, Michigan Technological University, 2005.

https://doi.org/10.37099/mtu.dc.etds/171

Follow this and additional works at: https://digitalcommons.mtu.edu/etds

8 Part of the Forest Sciences Commons 


\title{
VEGETATION AND HYDROLOGIC INFLUENCES ON CARBON AND NITROGEN IN SUBSURFACE WATER OF A FORESTED RIPARIAN WETLAND
}

\author{
By \\ Emily B.W. Calhoon
}

\begin{abstract}
A Thesis
Submitted in partial fulfillment of the requirements for the degree of MASTER OF SCIENCE IN FOREST ECOLOGY AND MANAGEMENT
\end{abstract}

Michigan Technological University 2005 
This thesis, "Vegetation and hydrologic influences on carbon and nitrogen in subsurface water of a forested riparian wetland", is hereby approved in partial fulfillment of the requirements of for the Degree of MASTER OF SCIENCE IN FOREST ECOLOGY AND MANAGEMENT.

Department:

School of Forest Resources and Environmental Science

Signatures:

Thesis Advisor

Margaret R. Gale

Department Dean

Margaret R. Gale

Date: 


\section{ACKNOWLEDGMENTS}

I would like to thank my advisor Dr. Margaret Gale for all her help and support with the research process. I would like to thank Jim McLaughlin for the help in support with field work, data analysis and writing. I would also like to thank the rest of my committee for their comments and suggestions: Marty Jurgensen, Janice Glime and John Gierke. I would like to give many thanks to my loving husband Kevin Calhoon who is always there to support me. Thanks to my good friend, Angela Piket, who understands the world of science. Thanks to Beth Leary and Jennifer Karberg for their assistance in the field. Funding acknowledgments go to the U.S. Forest Service, McIntire-Stennis Funds and Michigan Technological University. 


\section{TABLE OF CONTENTS}

List of figures.........................................................

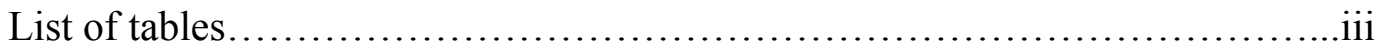

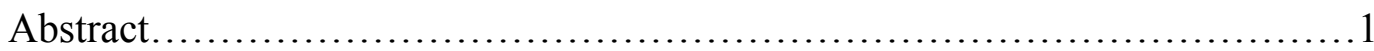

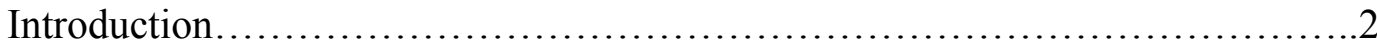

Methods.................................................................... 5

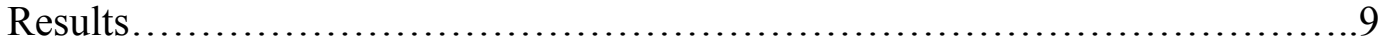

Discussion............................................................... 11

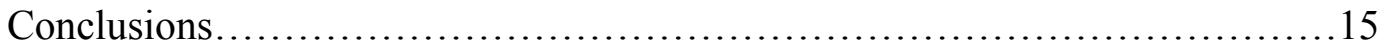

References............................................................. 16

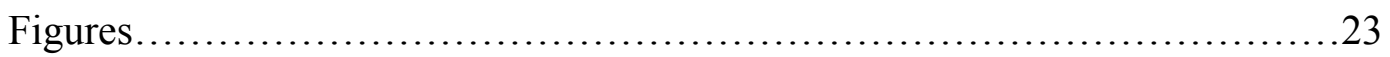

Tables...............................................................27

Appendix 1: Carbon, nitrogen and water table fluctuation data.................30

Appendix 2: Vegetation data....................................... 37 


\section{LIST OF FIGURES}

Figure 1. West Branch River subwatershed with the study site indicated

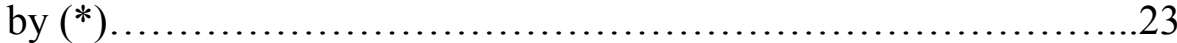

Figure 2. Transect and station layout on the West Branch study site.............24

Figure 3. Ordination diagram of detrended correspondence analysis of all vegetation species................................................ 25

Figure 4. Canonical correspondence analysis between water table fluctuation as well as vegetation species and DOC, DIC, $\mathrm{NO}_{3}{ }^{-}$and $\mathrm{NH}_{4}{ }^{+}$ .26

\section{LIST OF TABLES}

Table 1. Distance from the river and water table fluctuation correlation analysis with DIC, DOC, $\mathrm{NH}_{4}{ }^{+}$and $\mathrm{NO}_{3}{ }^{-}$

Table 2. One-way ANOVA and Tukey test results test results for DIC, DOC, $\mathrm{NH}_{4}{ }^{+}$and $\mathrm{NO}_{3}{ }^{-}$as the dependent variables and vegetation community

Table 3. Canonical correspondence analysis results - bi-plot scores..........28

Table 4. Vegetation species abbreviations...............................29 


\begin{abstract}
Vegetation communities affect carbon and nitrogen dynamics in the subsurface water of mineral wetlands through the quality of their litter, their uptake of nutrients, root exudation and their effects on redox potential. However, vegetation influence on subsurface nutrient dynamics is often overshadowed by the influences of hydrology, soils and geology on nutrient dynamics. The effects of vegetation communities on carbon and nitrogen dynamics are important to consider when managing land that may change vegetation type or quantity so that wetland ecosystem functions can be retained. This study was established to determine the magnitude of the influences and interaction of vegetation cover and hydrology, in the form of water table fluctuations, on carbon and nitrogen dynamics in a northern forested riparian wetland. Dissolved organic carbon (DOC), dissolved inorganic carbon (DIC), nitrate $\left(\mathrm{NO}_{3}{ }^{-}\right)$and ammonium $\left(\mathrm{NH}_{4}{ }^{+}\right)$ concentrations were collected from a piezometer network in four different vegetation communities and were found to show complex responses to vegetation cover and water table fluctuations. Dissolved organic carbon, $\mathrm{DIC}, \mathrm{NO}_{3}{ }^{-}$and $\mathrm{NH}_{4}{ }^{+}$concentrations were influenced by forest vegetation cover. Both $\mathrm{NO}_{3}{ }^{-}$and $\mathrm{NH}_{4}{ }^{+}$were also influenced by water table fluctuations. However, for $\mathrm{DOC}$ and $\mathrm{NH}_{4}{ }^{+}$concentrations there appeared to be more complex interactions than were measured by this study. The results of canonical correspondence analysis (CCA) and analysis of variance (ANOVA) did not correspond in relationship to the significance of vegetation communities. Dissolved inorganic carbon was influenced by an interaction between vegetation cover and water table fluctuations. More hydrological information is needed to make stronger conclusions about the relationship between vegetation and hydrology in controlling carbon and nitrogen dynamics in a forested riparian wetland.
\end{abstract}




\section{INTRODUCTION}

Wetlands are important ecosystems in the landscape that have unique hydrology, soils and vegetation. Wetlands are important to landscape hydrochemistry by retaining, transforming and transporting nutrients (Groffman et al. 1992, Hill and Devito 1997, Naiman and Decamps 1997). In this way, they influence groundwater and surface water by acting as filters to improve water quality as well as reducing flood pulses through their ability to retain water. One important wetland in the landscape is the forested riparian wetland, which are wetlands adjacent to lakes and rivers. Riparian wetlands are important because they are ecotones between aquatic and upland environments and directly affect the productivity and ecosystem function of stream and lakes systems (Stanford and Ward 1988, Valett et al. 1997, Verry et al. 2000). The individual influences of hydrology and vegetation on hydrochemistry of subsurface water within forested riparian wetlands have been studied throughout North America and in Europe (Peterjohn and Correll 1984, Pinay and Decamps 1988, Ford and Naiman 1989, Phillips et al. 1993, Cirmo and McDonnell 1997, Ohrui et al. 1999, Bischoff et al. 2001, Findlay et al. 2001, Groffman et al. 2002). Yet, interactions between hydrology and vegetation have not well understood in riparian wetlands.

Hydrology influences subsurface biogeochemical processes in forested riparian areas through water table fluctuations and pulses of water flow from rivers that create intermittent aerobic and anaerobic environments where different reactions take place (Regina et al. 1996, Blodau and Moore 2003). Fluctuating water tables and river pulses can also physically transport nutrients vertically and horizontally through the soil profile

(Werner and Höhener 2002). Although water table fluctuation regimes for wetlands have been determined (Roulet 1991), the effect of those water table fluctuations on carbon and nitrogen cycling is not well documented in forested riparian wetlands (Hill 1996).

Vegetation also influences carbon and nitrogen cycles through litterfall, decomposition and nutrient content (Aerts et al. 1999). Vegetation influences subsurface water biogeochemical processes by affecting redox status through its contribution of organic matter, oxidizing power, adventitious roots and growth patterns (Havens 1997, Tabacchi et al. 1998). Vegetation can influence nutrient cycling through its control of 
hydrologic processes and influence water table fluctuations through evapotranspiration processes (Williams and Lipscomb 1981, Verry, Riekerk 1989, Lundin, Bent 2001). The interaction between vegetation, hydrology and nutrient cycling is important in understanding how forested riparian wetland ecosystems function (Likens et al. 1970, Hanson et al. 1994, Stromberg et al. 1996, Bedford et al. 1999, Casey et al. 2004).

Two elements in subsurface water important to biogeochemical cycling are carbon and nitrogen. Carbon and nitrogen are key elements to riparian ecosystem functioning; carbon as a source of energy and nitrogen and a key element to organism functioning. Dissolved inorganic carbon (DIC) can be a source of carbon dioxide $\left(\mathrm{CO}_{2}\right)$ to the atmosphere as well as to the stream aquatic environment (Palmer et al. 2001, Jones et al. 2003). Some work in lakes and streams has reported the importance of DIC in surface water and have suggested that groundwater flow influences the amount of DIC in these systems (Amiotte-Suchet et al. 1999, Elder et al. 2000, Palmer et al. 2001, Ortega et al. 2002). It is known that wetlands and riparian areas are important in the aquatic cycling of DIC because of their high primary productivity and respiration rates which influence rivers through subsurface water exchange (Mitsch and Gosselink 2000, Jones et al. 2003). Vegetation can affect DIC by their roots respiring $\mathrm{CO}_{2}$, and also by producing organic carbon through the decomposition of litter or root exudation which microbes breakdown and thus respire $\mathrm{CO}_{2}$. However, hydrology can have an effect on DIC by water movement and weathering of soils and bedrock material and breaking down carbonates into their cation and carbonate molecules and leaving carbonates to contribute to subsurface water DIC.

Dissolved organic carbon (DOC), an important component in ecosystem productivity, increases in the subsurface water through microbial break down of organic matter and root exudation. Vegetation influences DOC through the quality and quantity of litter it provides as well as root exudation to the subsurface microbes (Aerts et al. 1999). Hydrology affects DOC through water table depth and flooding from surface waters (McLaughlin et al., Trettin et al. 1996). Vegetation and hydrology can play a role together in controlling DOC concentrations. Hydrology and vegetation influence redox potential which can affect sorption of DOC to iron ( $\mathrm{Fe}$ ) by oxidizing $\mathrm{Fe}$ to $\mathrm{Fe}^{+3}$ which favors sorption causing DOC to be removed from the subsurface water or creating 
reduced conditions which reduces $\mathrm{Fe}^{+3}$ to the more soluble form, $\mathrm{Fe}^{+2}$, which limits the sorption DOC (Heyes and Moore 1992, Moore et al. 1992, McLaughlin et al. 1994).

Inorganic nitrogen cycling in forested systems has also been reported to be influenced by hydrology (Devito and Dillon 1993, Bechtold et al. 2003) or vegetation (Vitousek et al. 1989, Aerts et al. 1999, Kiernan et al. 2003, Westbrook and Devito 2004). Riparian forests are known to have different inorganic nitrogen cycling processes than upland areas. In non-Alnus riparian communities, wetland vegetation can take up nitrogen in amounts that exceed mineralization rates (Bischoff et al. 2001) exerting a significant influence on nitrogen cycling. It has been found that hemlock riparian forests in the northeast have lower net $\mathrm{N}$ mineralization and nitrification rates than pine and maple upland areas (Hill and Shackleton 1989, Ohrui et al. 1999, Kiernan et al. 2003). Non-Alnus riparian forests tend to take up $\mathrm{NO}_{3}{ }^{-}$whereas uplands tend to produce inorganic nitrogen (Ohrui et al. 1999). These studies indicate that non-Alnus riparian areas may rely on inorganic nitrogen moving in from other areas of the landscape to meet their nitrogen needs, meaning that different vegetation communities in the landscape can act as a source or sink for inorganic nitrogen.

Riparian forests have been determined to remove nitrogen through uptake from subsurface waters in large amounts (Peterjohn and Correll 1984, Pinay and Decamps 1988, Correll and Weller 1989, Cooper 1990). However, the presence of Alnus in riparian forests has also been determined to increase $\mathrm{NO}_{3}{ }^{-}$and $\mathrm{NH}_{4}{ }^{+}$concentrations through an association with nitrogen-fixing bacteria (Ohrui et al. 1999, Kiernan et al. 2003). Hydrology controls nitrogen cycling by runoff and leaching $\mathrm{NO}_{3}{ }^{-}$into interstitial waters and out of soils (Bechtold et al. 2003) as well as water table depths affecting aeration and thus nitrogen transformations (Devito and Dillon 1993).

While many studies on $\mathrm{N}$ and $\mathrm{C}$ dynamics in North America and around the world have been done the Northern Lakes States is a unique region containing many riparian areas where information on the controls and interactions between vegetation, hydrology and carbon and nitrogen cycles is not complete. Much has been done in peatlands (Dalva and Moore 1991, Verry and Urban 1992, Blodau 2002) but mineral soils often found in riparian wetlands have yet to be studied in terms of the interactions between vegetation and hydrology controls on carbon and nitrogen cycling. 
The Northern Lake States contain many forested mineral and peatland riparian areas which are unique to the area. In northern peatlands carbon mineralization has been found to be influenced by interactions between hydrology and vegetation that are different with different peatlands studies (Blodau 2002). Controls of DOC in peatlands may include runoff, plant release, temperature and evaporation (Blodau 2002). However, the contribution of hydrology and vegetation to the interactive influence on DIC and DOC in mineral riparian wetlands of the Northern Lake States is not well understood.

For nitrogen, vegetation and mineralization have been determined to be the controlling influences of nitrogen cycling in a forested Minnesota bog (Urban and Eisenreich 1988). In a forested conifer peatland in Ontario retention of nitrogen is controlled by hydrological variables and the interactions between hydrology and vegetation (Devito and Dillon 1993). Studies that have investigated the interaction between vegetation, hydrology and nutrient cycling have been focused on peatlands in the Northern Lakes States (Devito and Dillon 1993, Blodau 2002) and are not representative of the interactions seen in the mineral riparian wetlands of the Northern Lakes states because of differences in vegetation, hydrology and geology.

The objectives of this study were to determine the influence and interactions of vegetation and hydrology on DIC, DOC, $\mathrm{NO}_{3}{ }^{-}$and $\mathrm{NH}_{4}{ }^{+}$concentrations across different vegetation communities of a Northern Lake States forested wetland complex. The hypotheses were: 1) hydrology, in the form of water table fluctuations and distance from a river, significantly influences DOC, DIC, $\mathrm{NO}_{3}{ }^{-}$and $\mathrm{NH}_{4}{ }^{+}$concentrations, 2) vegetation communities significantly affect DOC, DIC, $\mathrm{NO}_{3}{ }^{-}$and $\mathrm{NH}_{4}{ }^{+}$concentrations, 3 ) the influences of vegetation, water table fluctuation and distance from the river interact to control differences in DOC, DIC, $\mathrm{NO}_{3}{ }^{-}$and $\mathrm{NH}_{4}{ }^{+}$concentrations.

\section{METHODS}

Study Site

The study site is on the West Branch of the Sturgeon River (Figure 1), located in Alger county of the Upper Peninsula of Michigan $\left(46^{\circ} 10^{\prime} \mathrm{N}, 86^{\circ} 43^{\prime} \mathrm{W}\right)$. The $74 \mathrm{~km}^{2}$ 
$\left(28.6 \mathrm{mi}^{2}\right)$ watershed is part of the Sturgeon River watershed that drains into Lake Michigan. The West Branch subwatershed is a low gradient landscape that ranges from $240 \mathrm{~m}$ to $270 \mathrm{~m}$ in elevation from northwest to southeast. Bedrock geology of the site is Trenton Limestone and the glacial geology is classified as a peat and muck system (Natural Resources Conservation U.S. Department of Agriculture 1994, Michigan Natural Features Resources 1998). The soil is classified as a Kinross mucky sand which is sandy mixed, frigid and Typic Endoaquod (Trettin 1992, McLaughlin et al. 2000). The soil is acidic and poorly drained fine sand overlain by a $5-15 \mathrm{~cm}$ organic layer primarily made of decomposed Sphagnum (Trettin 1992, McLaughlin et al. 2000).

The study site is in a managed forested riparian wetland that has three main vegetation communities. The vegetation community closest to the river is a stand dominated by Alnus incana. The next vegetation community moving away from the river is a 15 year-old Pinus banksiana plantation intermixed with natural Picea mariana. The third vegetation community is a mature stand of Picea mariana, Larix laricina and Pinus banksiana. The groundcover is dominated by ericaceous shrubs and Sphagnum with other bryophytes being common in both the plantation and mature stands.

The climate of the West Branch subwatershed includes an annual average temperature of $5.4^{\circ} \mathrm{C}$ (minimum in January at $-11.8^{\circ} \mathrm{C}$ and maximum in July and August at $23.4^{\circ} \mathrm{C}$ ) and average total precipitation of $885 \mathrm{~mm}$ annually, with snowfall averaging 3,675 mm annually (National Weather Service 2005). Within the growing season, spring and fall are the wet seasons and summer generally has few precipitation events.

Three transects were established 75 meters apart and perpendicular to the West Branch River. Through all three vegetation communities, seven stations starting in the river were systematically established, two in the Alnus incana stand, two in the Pinus banksiana plantation and two in the mature Picea-Larix-Pinus stand (Figure 2). Each station (excluding the river station which is surface water) had two piezometers, $3.2 \mathrm{~cm}$ in diameter, at depths of $0.5 \mathrm{~m}$ and $1 \mathrm{~m}$ and a ceramic cup lysimeter at $0.25 \mathrm{~m}$. To test the hypotheses in this study data from all three depths were averaged for each station. 


\section{Sample collection}

Water samples were collected from each piezometer or lysimeter once a month from August - October in 2001 and June - October in 2002, stored on ice and transported to the lab. The water samples were filtered at $0.45 \mu \mathrm{m}$ and analyzed in the lab for carbon and nitrogen. Dissolved inorganic carbon and DOC from water samples collected in 2001 and 2002 were analyzed with a Shimadzu TOC/TIC 5000A Analyzer. Nitrate and ammonium from water samples collected in 2002 were analyzed with a Braan \& Luebbe Traacs 800 . Nitrate values are the sum of nitrate and nitrite. However, nitrite concentrations were found to be insignificant.

\section{Water table fluctuations and river influences}

Water table measurements were taken at each station from the $100 \mathrm{~cm}$ piezometers once a month July through October of 2001 and June through October of 2002. The fluctuation was recorded as the difference between the current month and the previous month. Differences for July 2001 and June 2002 were not calculated since there was no previous month of that year. Distance from the river to each station was measured using GPS coordinates.

\section{Vegetation survey}

Vegetation was surveyed in the summer of 2002 at each station of the three transects. Vegetation surveys were done using three categories: overstory, understory and groundcover. Overstory vegetation was surveyed in a $10 \mathrm{~m} \times 10 \mathrm{~m}$ plot centered at each sampling station. The species and percent cover of all vegetation over $1 \mathrm{~m}$ in height were recorded. Understory vegetation was surveyed in two $5 \mathrm{~m}$ x $5 \mathrm{~m}$ plots, located in the upper and lower corners within each $10 \times 10 \mathrm{~m}$ plot. The species and percent cover of all vegetation less than $1 \mathrm{~m}$ in height were recorded. Groundcover vegetation was surveyed using a Daubenmire frame $(50.5 \mathrm{~cm} \times 20.5 \mathrm{~cm})$ taking three random samples within one of the $5 \mathrm{~m} \mathrm{x} 5 \mathrm{~m}$ plots. The species and percent cover of all groundcover within the frame were recorded. Bryophytes, Carex, Dryopteris, Potamogeton, Solidago and Viola were only recorded to genus because of difficulties in keying them to species at 
the time of the survey. For statistical analyses, groundcover vegetation was divided further into non-bryophytes (further referred to as groundcover) and bryophytes.

\section{Statistics}

The influences of hydrology and vegetation on DIC, DOC, $\mathrm{NH}_{4}{ }^{+}$, and $\mathrm{NO}_{3}{ }^{-}$ concentrations were analyzed individually first, using correlation analysis, detrended correspondence analysis (DCA) and analysis of variance (ANOVA). Then the contribution of hydrology and vegetation as an interactive influence on DIC, DOC, $\mathrm{NH}_{4}^{+}$, and $\mathrm{NO}_{3}{ }^{-}$concentrations was analyzed using canonical correspondence analysis (CCA).

To determine hydrology influences, correlation analysis was used to look at the relationship between DIC, DOC, $\mathrm{NH}_{4}{ }^{+}$, and $\mathrm{NO}_{3}{ }^{-}$concentrations versus distance from the river and water table fluctuation. A significant correlation was considered a p-value of 0.05 or less.

To first determine if the three vegetation community types were statistically different in vegetation composition, vegetation cover values were analyzed using DCA (Hill and Gauch 1980). Vegetation cover values for each vegetation category of overstory, understory, groundcover and bryophytes as well as all vegetation cover values together were analyzed using DCA. The vegetation communities determined from DCA were then matched up with their corresponding station to create a new variable, vegetation community, which indicated the vegetation community each point of data was located in.

Mean DIC, DOC, $\mathrm{NH}_{4}{ }^{+}$, and $\mathrm{NO}_{3}{ }^{-}$concentrations as dependent variables were each compared using one way ANOVA with the independent variable of vegetation community. Nitrate and $\mathrm{NH}_{4}{ }^{+}$dominance in vegetation communities were examined at by taking the difference of the $\mathrm{NO}_{3}{ }^{-}$concentration from $\mathrm{NH}_{4}{ }^{+}$concentrations as the dependent variable in an ANOVA where vegetation community was the independent variable. Tukey's multiple comparison test was used for pair-wise comparison of treatments. For analyses, data for corresponding months of 2001 and 2002 were combined to look for seasonal differences. We did not look at annual differences as there were only three months of data in 2001. 
To determine the magnitude of vegetation communities and species with hydrologic controls on DIC, DOC, $\mathrm{NH}_{4}{ }^{+}$, and $\mathrm{NO}_{3}{ }^{-}$concentrations we used CCA (Braak 1986). The influence of individual species and vegetation communities as well as water table fluctuations were independent variables compared to $\mathrm{NO}_{3}{ }^{-}, \mathrm{NH}_{4}{ }^{+}$, DOC and DIC as dependent variables. CCA was performed with and without forward selection; both used 999 permutations for the Monte Carlo permutations test.

\section{RESULTS}

Differences in nutrient concentrations with distance from the river and water table fluctuation

Although correlation values ( $\mathrm{r}$ ) were low and negative, $\mathrm{DIC}$ and $\mathrm{NO}_{3}{ }^{-}$were significantly correlated with distance from the river (Table 1). Dissolved organic carbon and $\mathrm{NH}_{4}{ }^{+}$were not significantly correlated with distance from the river (Table 1). Dissolved inorganic carbon had the strongest relationship with distance from the river with an $r$ value of $-0.433(p<0.001)$. Water table fluctuations were not significantly correlated with any of the concentrations (Table 1).

\section{Differences in nutrients concentrations among vegetation communities}

Detrended correspondence analysis revealed four vegetation communities: riparian (station 1), edge (station 2), plantation (stations 3 and 4) and mature stand (stations 5 and 6). As was expected, the overstory vegetation corresponded to the three vegetation communities apparent in the field as well as a fourth intermediate vegetation community: the Alnus incana riparian area, the edge between the riparian area and the plantation, the Pinus banksiana plantation and the Picea mariana-Larix laricina-Pinus banksiana mature stand.

ANOVA indicated that DIC, $\mathrm{NO}_{3}{ }^{-}$and DOC were significantly different among vegetation communities $(\alpha=0.05, \mathrm{p}<0.001)$, but there was no difference in $\mathrm{NH}^{+}$ concentrations. Dissolved inorganic carbon and $\mathrm{NO}_{3}{ }^{-}$concentrations were highest in the riparian area (Table 2). The pattern of DOC was not so easily distinguished, but it was 
higher in the plantation compared to the edge (Table 2). The dominant dissolved inorganic nitrogen form was different $(\mathrm{p}<0.001)$ among the vegetation communities. Nitrate concentrations were higher than $\mathrm{NH}_{4}{ }^{+}$concentrations in the riparian area (Table 2). Ammonium concentrations were higher than $\mathrm{NO}_{3}{ }^{-}$concentrations in the plantation and mature communities.

\section{Vegetation and hydrology influences on nutrient concentrations}

The influence of vegetation cover and water table fluctuations on DIC, DOC, $\mathrm{NO}_{3}{ }^{-}$and $\mathrm{NH}_{4}{ }^{+}$were analyzed using $\mathrm{CCA}$. The eigenvalues for axes 1 and 2 were low at 0.161 and 0.001 , respectively, using forward selection, but axis 1 explained $99.1 \%$ and axis 2 explained $0.5 \%$ of the species-environmental relation variation. The speciesenvironmental variables correlation for axis 1 was 0.758 and 0.373 for axis 2 .

Axis 1 represented mainly differences in vegetation communities. It separated the riparian vegetation community from the plantation and mature stand vegetation communities. There seemed to be a separation of forest vegetation species and more open and riparian vegetation species. The vegetation species that were most correlated to axis 1 were overstory Acer rubrum and Alnus incana, understory Cornus foemina and Alnus incana, groundcover Galium boreale, Spartina pectinata and Onoclea sensibilis (Figure 4). Overstory and understory Alnus incana was highly correlated with axis 1, which differentiates vegetation communities, indicating the importance of Alnus incana in the riparian wetland. Axis 2 represented differences in water table fluctuation. The mature community was most strongly related to water table fluctuations followed by the plantation community, riparian community and edge community.

Dissolved inorganic carbon concentrations were positively correlated to riparian species and not correlated to water table fluctuations (Figure 4). Ammonium concentrations were positively related to plantation and mature species as well as being positively related to water table fluctuations (Figure 4). Dissolved organic carbon concentrations were positively correlated with plantation and mature species not correlated to water table fluctuations. Nitrate concentrations were positively related to the riparian vegetation species and negatively related to water table fluctuations. Dissolved inorganic carbon concentrations had the strongest relationship with vegetation 
community. Both $\mathrm{NO}_{3}{ }^{-}$and $\mathrm{NH}_{4}{ }^{+}$concentrations had strong relationships to water table fluctuation, but DIC and DOC concentrations did not have a relationship with water table fluctuation (Figure 4).

\section{DISCUSSION}

\section{Carbon}

Dissolved inorganic carbon concentrations were influenced by vegetation communities and not the hydrologic factor of water table fluctuation. Riparian areas have been found to have high productivity (Naiman and Decamps 1997, Mitsch and Gosselink 2000). A high productivity increases decomposition and microbial respiration which increases $\mathrm{CO}_{2}$ being released into the soil matrix and subsurface water. The $\mathrm{CO}_{2}$ produced by respiration remains dissolved in the subsurface water and can combine with hydrogen ions in the acidic environment to form bicarbonate and other forms of DIC depending on the carbonate equilibrium (Stumm and Morgan 1981). A number of studies from North America and Europe have shown plant root and microbial respiration are major components of DIC in wetlands and riparian areas (Findlay et al. 1993, Schindler and Krabbenhoft 1998, Amiotte-Suchet et al. 1999). The riparian area in this study contains Alnus incana which is known to have a low C:N ratio (Bischoff et al. 2001) increasing decomposition rates (Brady and Weil 2002) and respiration rates also contributing to the increased $\mathrm{CO}_{2}$ available as a form of DIC. Elder et al. (2000) found DIC concentrations similar to the concentrations in this study in riparian peatlands of northern Wisconsin. However, they did not find a significant decrease in DIC concentrations moving away from the stream through different vegetation communities as this study found. This indicates that the mineral riparian wetland is an important vegetation community to DIC.

The peak in DIC concentration in the riparian area could be attributed to $\mathrm{CO}_{2}$ from respiration not escaping into the atmosphere as fast as in other areas of the wetland because of the generally shallower water table in the riparian zone. This is due to slow diffusion of $\mathrm{CO}_{2}$ through water. Carbon dioxide moves through water slower than air, 
and the water table is higher in the riparian area than in other vegetation communities of the wetland. This theory is supported by Findlay et al. (1993) who found that in near stream flowpaths DIC concentrations increased mainly due to microbial respiration and secondarily to weathering of calcium carbonates.

A peak in calcium (data not shown) was also found in the riparian area which indicates that some of the DIC could be coming from weathered materials. Calcium carbonates from the bedrock geology could be disassociating and moving in the groundwater towards the surface. The glacial geology and sandy soils make groundwater influences likely in the area (Elder et al. 2000). Therefore, the riparian area may have an upwelling of groundwater bringing in DIC from the aquifer below. More information on the riparian community, water table fluctuations, and water movement are required to determine the amount of water saturation and the presence of groundwater upwelling in this area. In particular, deeper wells and piezometers, stable isotopes, dyes and wells and piezometers at different depths are required to determine the DIC movement in groundwater.

Vegetation and not hydrologic influences seem to be affecting DOC (as seen in CCA), however there were not significant differences between the riparian and forest communities (in ANOVA analyses). Different things could be contributing to the DOC concentrations in different vegetation communities. The plantation and mature communities have lower water tables and thus more aerobic environments than the riparian community, which has a consistently high water table. Aerobic environments decompose organic matter more completely (Alexander 1977) leaving less DOC in the subsurface water. However, the DOC left is recalcitrant and not easily broken down.

Dissolved organic carbon concentrations are also known to be associated with metal oxides which bind with DOC and precipitate out of solution (McLaughlin et al. 1994, Carlyle and Hill 2001, Jacinthe et al. 2003). Iron (Fe) is known to bond with DOC in its oxidized form, $\mathrm{Fe}^{+3}$. In wetland areas where anoxic conditions form from consistent high water tables, $\mathrm{Fe}^{+3}$ is reduced and can be easily leached out of the soil so sorption of DOC is not as great, leaving greater concentrations of DOC in solution (McLaughlin et al. 1994). In the sandy soils of the West Branch study site $\mathrm{Fe}^{+2}$ has been reduced and leached out of the soil by periodic high water tables and thus there is no 
sorption of DOC out of the subsurface water. Thus the recalcitrant DOC stays in the subsurface water of the plantation and mature stands causing accumulation of DOC. The plantation has the highest mean concentration of DOC which could be due to the mature stand having more Sphagnum (data not shown) which can hold water closer to the surface (Halsey et al. 2000) and create less aerobic conditions. The riparian deciduous communities are known to more productive and have higher leaf-litter nutrient concentrations than other conifer communities (Tabacchi et al. 1998, Aerts et al. 1999) as well as having higher litter quality, which leads to increased carbon turnover and more complete decomposition, leaving less carbon in the subsurface water as DOC. The anaerobic conditions of the riparian area create a less complete decomposition than the aerobic plantation and mature communities because electron acceptors other than oxygen are being used (Alexander 1977). However, the increased litter quality and production overcome anaerobic conditions at this site so that the riparian community, even though it had a lower mean DOC concentration, was not significantly different in DOC concentration from the plantation or mature communities.

Dissolved organic carbon concentration was strongly correlated to the first axis in CCA which reflects mainly vegetation differences and not correlated to the second axis which reflects water table fluctuations differences. Increased concentrations of DOC were found in plantation and mature communities with water table fluctuations having no effect. This indicates that DOC is influenced mainly by vegetation and positively influenced by certain types of vegetation communities.

\section{Nitrogen}

There was a significant peak of $\mathrm{NO}_{3}{ }^{-}$at the riparian community that corresponded to the results in CCA showing a positive relationship to riparian vegetation along with a stronger negative relationship to water table fluctuation. In other studies, Alnus incana in New York has been associated with high $\mathrm{NO}_{3}{ }^{-}$levels in wetlands (Kiernan et al. 2003). The wetland in this study showed the same pattern of increased $\mathrm{NO}_{3}{ }^{-}$concentrations in the riparian area where Alnus incana was present. Alnus incana was significantly related to riparian vegetation community, where $\mathrm{NO}_{3}{ }^{-}$had a peak. Alnus incana has two attributes that could have lead to increased $\mathrm{NO}_{3}{ }^{-}$concentrations in the subsurface water 
surrounding it. Alnus spp. have nitrogen fixing bacteria associated with their roots. Coupled with high aeration around their roots, this could lead to high rates of nitrification within the rhizosphere soil of the Alnus spp. roots (Schröder 1989). Moreover, Alnus incana generally has low nitrogen use efficiency, resulting in higher litter nitrogen concentrations that can be mineralized and nitrified to $\mathrm{NO}_{3}{ }^{-}$(Bischoff et al. 2001).

The riparian vegetation community lives in a consistently high water table that intuitively would seem to inhibit nitrification due to low availability of oxygen for nitrification (Mitsch and Gosselink 2000). Yet, Westbrook and Devito (2004) have found high gross nitrification rates in saturated soils and Luther and Popp (2002) found that nitrification can occur in the absence of oxygen. These two studies support the possibility that you can have high $\mathrm{NO}_{3}{ }^{-}$concentrations under saturated conditions. Another possibility is that $\mathrm{NO}_{3}{ }^{-}$concentrations are higher in the riparian community because the movement of the river water that may aerate the subsurface water enough to create conditions for nitrification rates to outweigh denitrification rates. The higher quality of organic matter in the riparian area, due to Alnus incana, than the plantation and mature communities could lead to higher nitrification rates in the riparian community than the other vegetation communities. The high $\mathrm{NO}_{3}{ }^{-}$concentrations in the riparian zone could also be from groundwater upwelling. In their review, Cirmo and McDonnell (1997) reported that groundwater is relatively high in $\mathrm{NO}_{3}{ }^{-}$concentration and may contribute to high $\mathrm{NO}_{3}{ }^{-}$concentrations in riparian areas where conductivity and calcium (data not published) indicate the possibility of groundwater influence. More data on hydrologic factors of water table depth and water flow patterns would be needed to make a conclusion on the sources of influence of $\mathrm{NO}_{3}{ }^{-}$in this riparian wetland.

Ammonium concentrations were positively related to the plantation and mature stand vegetation communities, but it had a higher positive relationship to water table fluctuations. Analysis from CCA did not correspond to the above findings; $\mathrm{NH}_{4}{ }^{+}$ concentrations were not significantly different across vegetation communities using ANOVA. However, $\mathrm{NH}_{4}{ }^{+}$concentrations did increase from the riparian and edge communities to the forest communities. Mineralization of $\mathrm{N}_{\text {into }} \mathrm{NH}_{4}{ }^{+}$occurs in both aerobic and anaerobic conditions but at different rates due to different microbes initiating 
the reactions (Gale and Gilmour 1988) thus hydrology can have an effect on the rate of ammonification due to its influence on creating aerobic and anaerobic conditions.

Ammonium concentration means and water table fluctuations were most positively related to the mature vegetation community followed by the plantation, edge and then riparian vegetation communities. The lack of difference in $\mathrm{NH}_{4}{ }^{+}$across vegetation communities in ANOVA and only low relationship to the mature and plantation communities in CCA could due to a number of factors. In the riparian community Alnus incana is fixing nitrogen but due to the peak in $\mathrm{NO}_{3}{ }^{-}$concentrations it seems that $\mathrm{NH}_{4}{ }^{+}$is rapidly nitrifying. Low $\mathrm{NO}_{3}{ }^{-}$concentrations in the mature and plantation communities indicate low nitrification rates in these communities thus leaving more $\mathrm{NH}_{4}{ }^{+}$in the subsurface water. However, without nitrogen fixers like Alnus incana the initial $\mathrm{NH}_{4}^{+}$concentrations in the plantation and mature communities were lower than those of the riparian community. Nitrate was negatively related to water table depth supporting that in the West Branch wetland changes in concentrations of $\mathrm{NH}_{4}{ }^{+}$or $\mathrm{NO}_{3}{ }^{-}$ are due to microbial processing and influenced mainly by water table fluctuations. The lack of differences across vegetation communities could be due to the high variability in $\mathrm{NH}_{4}{ }^{+}$and $\mathrm{NO}_{3}{ }^{-}$concentrations and also due to a small sample size.

\section{CONCLUSIONS}

In this study, vegetation communities influence DOC, DIC, $\mathrm{NO}_{3}{ }^{-}$and $\mathrm{NH}_{4}{ }^{+}$ concentrations; however, the magnitude of this influence was strongest in DIC concentrations. Hydrology, in the form of water table fluctuations, interacted, as a stronger contributor, with vegetation to influence $\mathrm{NO}_{3}{ }^{-}$and $\mathrm{NH}_{4}{ }^{+}$but did not influence on DOC and DIC. The interaction between hydrology and vegetation would be better understood with more detailed hydrological information. More research should be done to determine subsurface flowpaths and groundwater upwelling and downwelling points in this wetland and how these hydrological factors affect nitrogen and carbon processes. Vegetation is the overriding factor in this study, which may or may not be influenced by hydrology. 


\section{REFERENCES}

Aerts, R., J. T. A. Verhoeven, and D. F. Whigham. 1999. Plant-mediated controls on nutrients cycling in temperate fens and bogs. Ecology 80:2170-2181.

Alexander, M. 1977. Introduction to Soil Microbiology, Second edition. Krieger Publishing Company, Malabar, Florida.

Amiotte-Suchet, P., D. Aubert, J. L. Probst, F. Gauthier-Lafaye, A. Probst, F. Andreux, and D. Viville. 1999. delta 13C pattern of dissolved inorganic carbon in a small granitic catchment: the Strengbach case study (Vosges mountains, France). Chemical Geology 159:129-145.

Bechtold, J. S., R. T. Edwards, and R. J. Naiman. 2003. Biotic versus hydrologic control over seasonal nitrate leaching in a floodplain forest. Biogeochemistry 63:53-72.

Bedford, B. L., M. R. Walbridge, and A. Aldous. 1999. Patterns in nutrient availability and plant diversity of temperate north American wetlands. Ecology 80:21512169.

Bent, G. C. 2001. Effects of forest-management activities on runoff components and ground-water recharge to Quabbin Reservoir, center al Massachusetts. Forest Ecology and Management 143:115-129.

Bischoff, J. M., P. Bukaveckas, M. J. Mitchell, and T. Hurd. 2001. N storage and cycling in vegetation of a forested wetlands: implications for watershed processing. Water, Air \& Soil Pollution 128:97-114.

Blodau, C. 2002. Carbon cycling in peatlands - a review of processes and controls. Environmental Reviews 10:111-134.

Blodau, C., and T. R. Moore. 2003. Experimental response of peatland carbon dynamics to a water table fluctuation. Aquatic Sciences 65:47-62.

Braak, C. J. F. 1986. Canonical Correspondence Analysis: A New Eigenvector Technique for Multivariate Direct Gradient Analysis. Ecology 67:1167-1179.

Brady, N. C., and R. R. Weil. 2002. The Nature and Properties of Soils, Thirteenth edition. Prentice Hall, Upper Saddle River, New Jersey. 
Carlyle, G. C., and A. R. Hill. 2001. Groundwater phosphate dynamics in a river riparian zone: effects of hydrologic flowpaths, lithology and redox chemistry. Journal of Hydrology 247:151-168.

Casey, R. E., M. D. Taylor, and S. J. Klaine. 2004. Localization of denitrification activity in macropores of a riparian wetland. Soil Biology \& Biochemistry 36:563-569.

Cirmo, C. P., and J. J. McDonnell. 1997. Linking the hydrologic and biogeochemical controls of nitrogen transport in near-stream zones of temperate-forested catchments: a review. Journal of Hydrology 199:88-120.

Cooper, A. B. 1990. Nitrate depletion in the riparian zone and stream channel of a small headwater catchment. Hydrobiologia 202:13-26.

Correll, D. L., and D. E. Weller. 1989. Factors limiting processes in freshwater wetlands: an agricultural primary stream riparian forest. Pages 9-23 in R. R. Sharitz and J. W. Gibbons, editors. Freshwater Wetlands and Wildlife. U.S. Department of Energy, Charleston, South Carolina.

Dalva, M., and T. R. Moore. 1991. Sources and sinks of dissolved organic carbon in a forested swamp catchment. Biogeochemistry 15:1-19.

Devito, K. J., and P. J. Dillon. 1993. The influence of hydrologic conditions and peat oxia on the phosphorus and nitrogen dynamics in a conifer swamp. Water Resources Research 29:2675-2685.

Elder, J. F., N. B. Rybicki, V. Carter, and V. Weintraub. 2000. Sources and yields of dissolved carbon in northern Wisconsin stream catchments with differing amounts of peatland. Wetlands 20:113-125.

Findlay, S., J. M. Quinn, C. W. Hickey, G. Burrell, and M. Downes. 2001. Effects of land use and riparian flowpath on delivery of dissolved organic carbon to streams. Limnology and Oceanography:345-355.

Findlay, S., D. Strayer, C. Goumbala, and K. Gould. 1993. Metabolism of streamwater dissolved organic carbon in the shallow hyporheic zone. Limnology and Oceanography 38:1493-1499.

Ford, T. E., and R. J. Naiman. 1989. Groundwater-surface water relationships in boreal forest watersheds: dissolved organic carbon and inorganic nutrient dynamics. Canadian Journal of Fisheries and Aquatic Science 46:41-49. 
Gale, P. M., and J. T. Gilmour. 1988. Net mineralization of carbon and nitrogen under aerobic and anaerobic conditions. Soil Science Society of America Journal 52:1006-1010.

Groffman, P. M., N. J. Boulware, W. C. Zipperer, R. V. Pouyat, L. E. Band, and M. F. Colosimo. 2002. Soil Nitrogen Cycle Processes in Urban Riparian Zones. Environmental science \& technology 36:4547 (4546 pages).

Groffman, P. M., A. J. Gold, and R. C. Simmons. 1992. Nitrate Dynamics in Riparian Forests: Microbial Studies. Journal of Environmental Quality 21:666-671.

Halsey, L. A., D. H. Vitt, and L. D. Gignac. 2000. Sphagnum-dominated peatlands in North America Since the last glacial maximum: their occurrence and extent. The Bryologist 103:334-352.

Hanson, G. C., P. M. Groffman, and A. J. Gold. 1994. Symptoms of nitrogen saturation in a riparian wetland. Ecological Applications 4:750-756.

Havens, K. J. 1997. The effect of vegetation on soil redox within a seasonally flooded forested system. Wetlands 17:237.

Heyes, A., and T. R. Moore. 1992. The influence of dissolved organic carbon and anaerobic conditions on mineral weathering. Soil Science 154:226-236.

Hill, A. R. 1996. Nitrate removal in stream riparian zones. Journal of Environmental Quality 25:743-755.

Hill, A. R., and K. J. Devito. 1997. Hydrological-chemical interactions in headwater forest wetlands. Pages 213-230 in C. C. Trettin, M. F. Jurgensen, D. F. Grigal, M. R. Gale, and J. K. Jeglum, editors. Northern Forested Wetlands: ecology and management. Lewis, New York, New York.

Hill, A. R., and M. Shackleton. 1989. Soil N mineralization and nitrification in relation to nitrogen solution chemistry in a small forested watershed. Biogeochemistry 8:167-184.

Hill, M. O., and H. G. J. Gauch. 1980. Detrended correspondence analysis: An improved ordination technique. Vegetatio 42:47-58.

Jacinthe, P. A., P. M. Groffman, and A. J. Gold. 2003. Dissolved organic carbon dynamics in a riparian aquifer: Effects of hydrology and nitrate enrichment. Journal of Environmental Quality 32:1365-1374. 
Jones, J. B. J., E. H. Stanley, and P. J. Mulholland. 2003. Long-term decline in carbon dioxide supersaturation in rivers across the contiguous United States. Geophysical Research Letters 30:1495.

Kiernan, B. D., T. M. Hurd, and D. J. Raynal. 2003. Abundance of Alnus incana ssp. rugosa in Adirondack Mountain shrub wetlands and its influence on inorganic nitrogen. Environmental Pollution 123:347-354.

Likens, G. E., F. H. Bormann, N. M. Johnson, and R. S. Pierce. 1970. Effects of forest cutting and herbicide treatment on nutrient budgets in Hubbard-Brook watershed ecosystem. Ecological Monographs 40:23-47.

Lundin, L. 1999. Effects on hydrology and surface water chemistry of regeneration cuttings in peatland forests. International Peat Journal 9:118-126.

Luther, G. W. I., and J. I. Popp. 2002. Kinetics of the Abiotic Reduction of Polymeric Manganese Dioxide by Nitrite: An Anaerobic Nitrification Reaction. Aquatic Geochemistry 8:15-36.

McLaughlin, J. W., M. R. Gale, M. F. Jurgensen, and C. C. Trettin. 2000. Soil organic matter and nitrogen cycling in response to harvesting, mechanical site preparation, and fertilization in a wet land with mineral substrate. Forest Ecology and Management 129:7-23.

McLaughlin, J. W., J. C. Lewin, D. D. Reed, C. C. Trettin, M. F. Jurgensen, and M. R. Gale. 1994. Soil factors related to dissolved organic carbon concentrations in a black spruce swamp, Michigan. Soil Science 158:454-463.

Mitsch, W. J., and J. G. Gosselink. 2000. Wetlands, Third edition. John Wiley \& Sons, Inc., New York, NY.

Moore, T. R., W. d. Souza, and J.-F. Koprivnjak. 1992. Controls on the sorption of dissolved organic carbon by soils. Soil Science 154:120-129.

Naiman, R. J., and H. Decamps. 1997. The ecology of interfaces: riparian zones. Annual review of ecology and systematics 28:621-658.

National Weather Service, M. M. 2005. Annual and monthly temperature and precipitation normals and records for Munising, MI. in. Nation Weather Service, Marquette, MI. 
Ohrui, K., M. J. Mitchell, and J. M. Bischoff. 1999. Effect of landscape position on N mineralization and nitrification in a forested watershed in the Adirondak Mountains of New York. Canadian Journal of Forest Research 29:497-508.

Ortega, T., R. Ponce, J. M. Forja, and A. Gomez-Parra. 2002. Inorganic carbon fluxes at the water-sediment interface in five littoral systems in Spain (southern Europe). Hydrobiologia 469:109-116.

Palmer, S. M., D. Hope, M. F. Billett, J. J. C. Dawson, and C. L. Bryant. 2001. Sources of organic and inorganic carbon in a headwater stream: Evidence from carbon isotope studies. Biogeochemistry 52:321-338.

Peterjohn, W. T., and D. L. Correll. 1984. Nutrient dynamics in an agricultural watershed: observations on the role of a riparian forest. Ecology 65:1466-1475.

Phillips, P. J., J. M. Denver, R. J. Shedlock, and P. A. Hamilton. 1993. Effect of a forested wetlands on nitrate concentrations in ground water and surface water on the Delmarva Peninsula. Wetlands 13:75-83.

Pinay, G., and H. Decamps. 1988. The role of riparian woods in regulating nitrogen fluxes between the alluvial aquifer and surface water: a conceptual model. Regulated Rivers: Research and Management 2:507-516.

Regina, K., H. Nykänen, J. Silvola, and P. J. Martikainen. 1996. Fluxes of nitrous oxide from boreal peatlands as affected by peatland type, water table level and nitrification capacity. Biogeochemistry 35:401-418.

Resources, M. N. F. I. a. M. D. o. N. 1998. Template - Quaternary Geology. Lansing, MI. Riekerk, H. 1989. Influences of silvicultural practices on hydrology of pine flatwoods in Florida. Water Resources Research 25:713-719.

Roulet, N. T. 1991. Surface level and water table fluctuations in a subarctic fen. Arctic and Alpine Research 23:303-310.

Schindler, J. E., and D. P. Krabbenhoft. 1998. The hyporheic zone as a source of dissolved organic carbon and carbon gases to a temperate forested stream. Biogeochemistry 43:157-174.

Schröder, P. 1989. Characterization of thermo-osmotic gas transport mechanism in Alnus glutinosa (L.) Gaertn. Trees - Structure and Function 3:38-44. 
Stanford, J. A., and J. V. Ward. 1988. The hyporheic habitat of river ecosystems. Nature 355:64-66.

Stromberg, J. C., R. Tiller, and B. Richter. 1996. Effects of groundwater decline on riparian vegetation of semiarid regions: the San Pedro, Arizona. Ecological Applications 6:113-131.

Stumm, W., and J. J. Morgan. 1981. Aquatic Chemistry. Wiley, New York, New York.

Tabacchi, E., D. L. Correll, R. Hauer, G. Pinay, A.-M. Planty-Tabacchi, and R. C. Wissmar. 1998. Development, maintenance and role of riparian vegetation in the river landscape. Freshwater Biology 40:497-516.

Trettin, C. C. 1992. Silvicultural effects on functional processes of a boreal forest wetland. Ph.D. North Carolina State University, Raleigh, NC.

Trettin, C. C., M. Davidian, M. F. Jurgensen, and R. Lea. 1996. Organic matter decomposition following harvesting and site preparation of a forested wetland. Soil Science Society America Journal 60:1994-2003.

U.S. Department of Agriculture, N. R. C. S. 1994. State Soil Geographic (STATSGO) data base for Michigan. Fort Worth, Texas.

Urban, N. R., and S. J. Eisenreich. 1988. Nitrogen cycling in a forested Minnesota bog. Canadian Journal of Botany 66:435-449.

Valett, H. M., C. N. Dahm, M. E. Campana, J. A. Morrice, M. A. Baker, and C. S. Fellows. 1997. Hydrologic influences on groundwater-surface water ecotones: heterogeneity in nutrient composition and retention. Journal of the North American Benthological Society 16:239-247.

Verry, E. S. 1986. Forest harvesting and water: the lake states experience. Water Resources Bulletin 22:1039-1047.

Verry, E. S., J. W. Hornbeck, and C. A. Dolloff, editors. 2000. Riparian Management in Forests of the Continental Eastern United States. Lewis Publishers, Boca Raton, FL.

Verry, E. S., and N. R. Urban. 1992. Nutrient cycling at Marcell Bog, Minnesota. Suo 43:147-153. 
Vitousek, P. M., P. A. Matson, and K. Van Cleve. 1989. Nitrogen availability and nitrification during succession: primary, secondary, and old-field seres. Plant and Soil 115:229-239.

Werner, D., and P. Höhener. 2002. The influence of water table fluctuations on the volatilization of contaminants from groundwater. Groundwater Quality: Natural and Enhanced Restoration of Groundwater Pollution IAHS Publ. no. 275:213218.

Westbrook, C. J., and K. J. Devito. 2004. Gross nitrogen transformations in soils from uncut and cut boreal upland and peatland conifers forest stands. Biogeochemistry 68:33-50.

Williams, T. M., and D. J. Lipscomb. 1981. Water table rise after cutting on coastal plain soils. Southern Journal of Applied Forestry 5:46-48. 


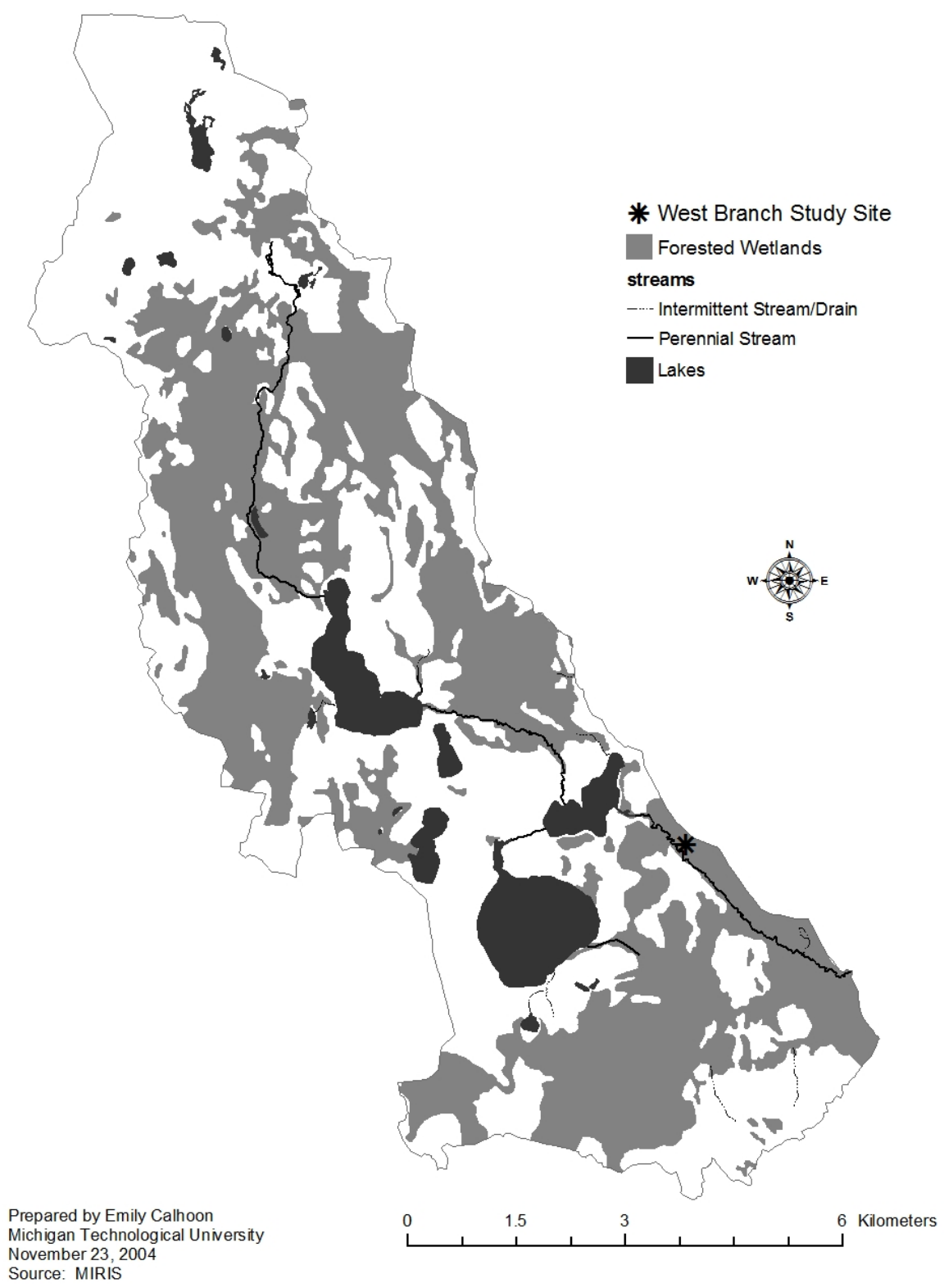

Figure 1. West Branch River subwatershed with the study site indicated by $(*)$. 


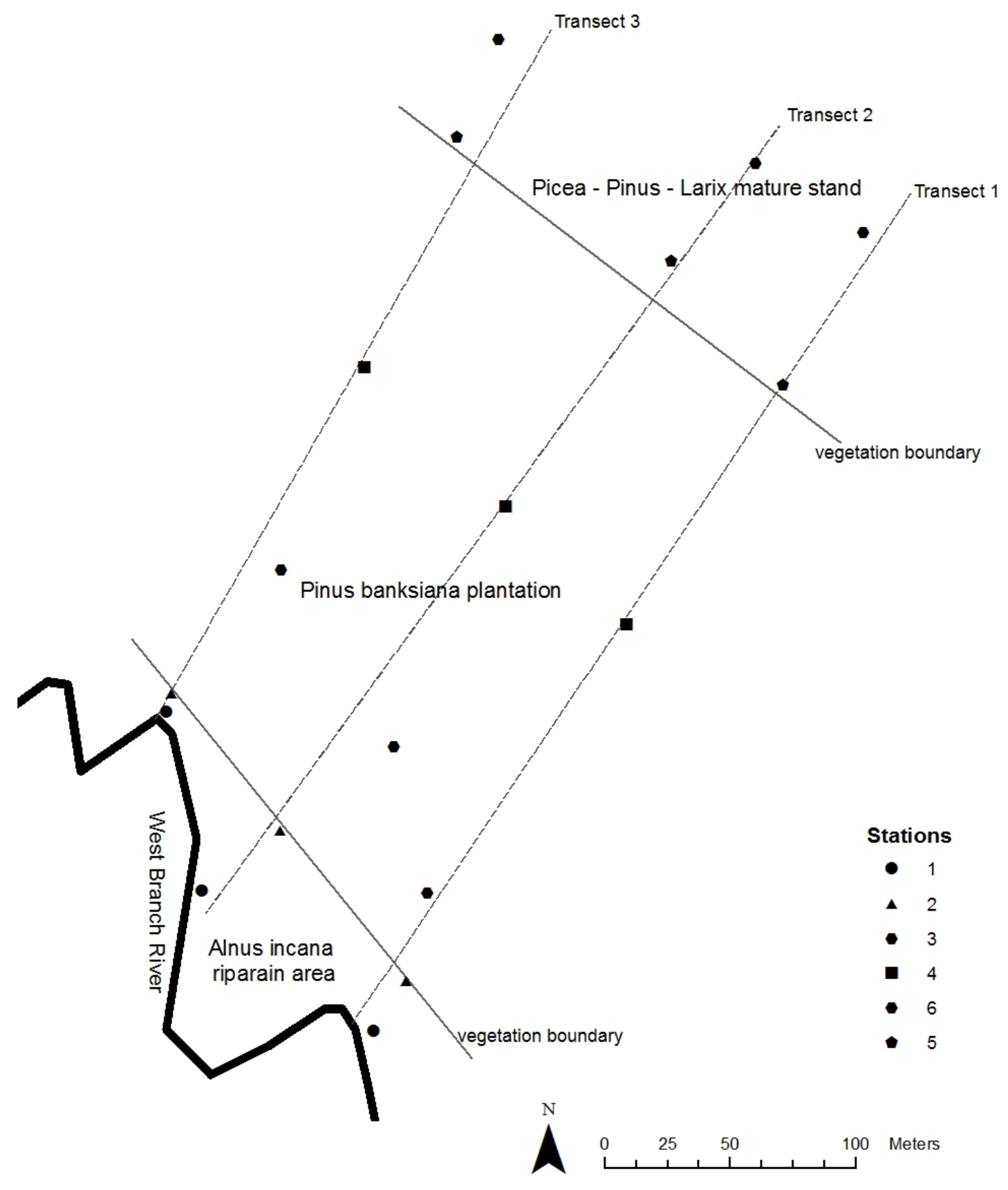

Figure 2. Transect and station layout on the West Branch riparian wetland study site. 


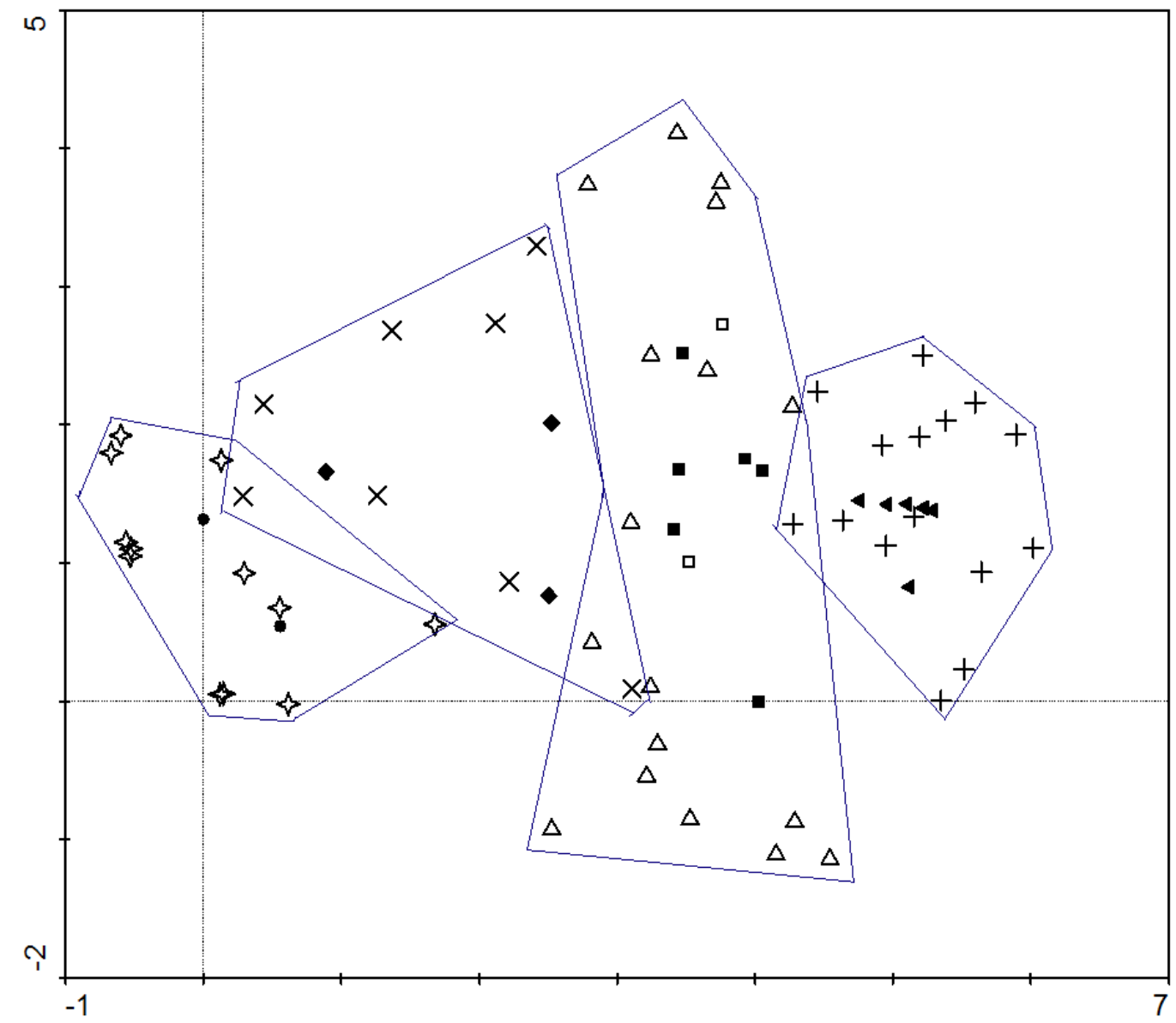

Figure 3. Ordination diagram of detrended correspondence analysis of all vegetation species. Species in the same vegetation community are circled. Species in the four vegetation communities are represented by open symbols: riparian species (star), edge species (X), plantation species $(\Delta)$ and mature stand species $(+)$. Species occurring in many vegetation communities are indicated with an open square ( $\square)$. Stations at the study site are indicated in closed symbols: station 1 (circle), station 2 (diamond), stations 3 and 4 (square) and stations 5 and 6 (triangle). 


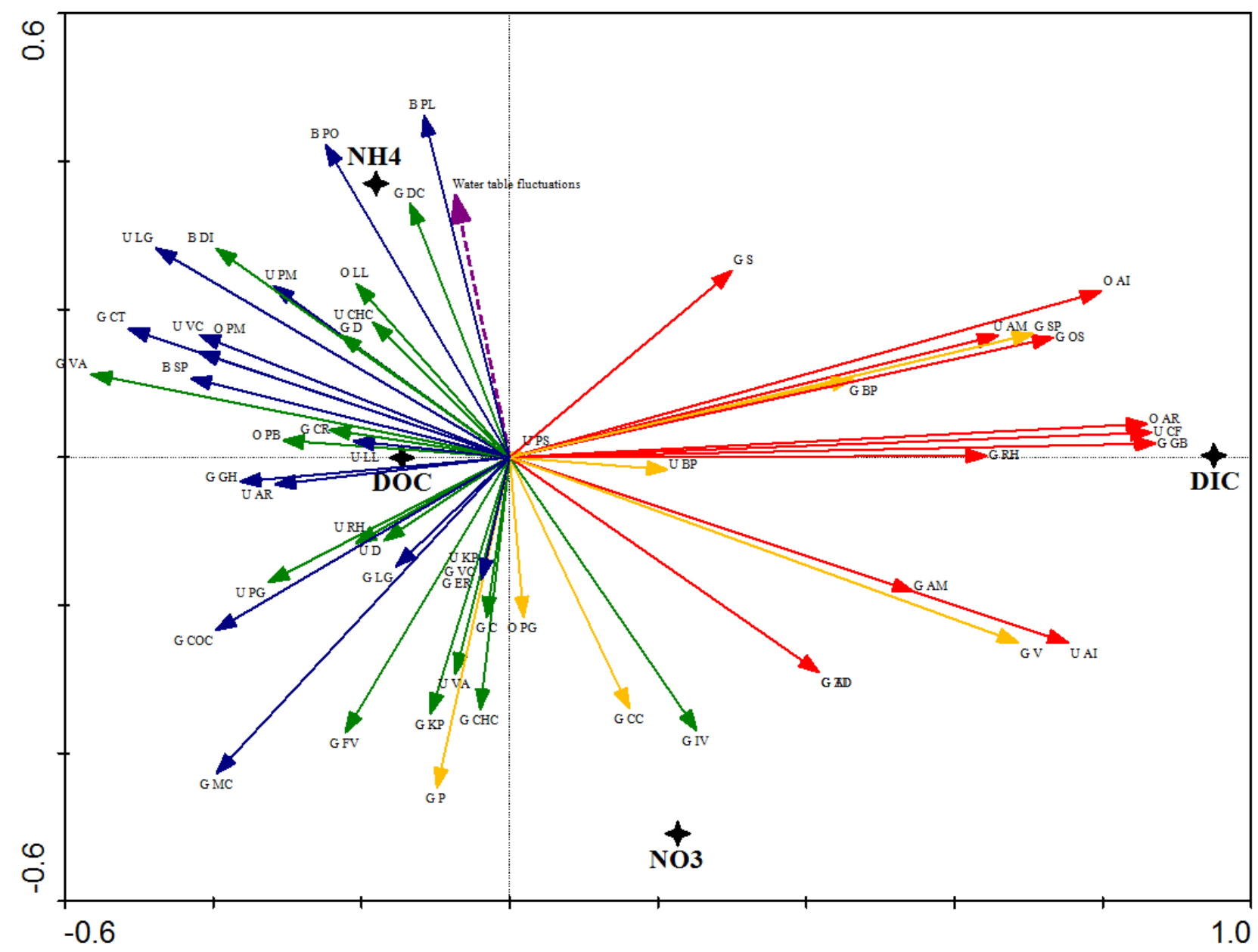

Figure 4. Canonical correspondence analysis between water table fluctuation as well as vegetation species and $\mathrm{DOC}, \mathrm{DIC}, \mathrm{NO}_{3}{ }^{-}, \mathrm{NH}_{4}^{+}$. Species are divided by vegetation community: riparian vegetation (red), edge vegetation (yellow), plantation vegetation (green), mature stand (blue). Water table fluctuations are represented by a dashed purple line. Vegetation species abbreviation list can be found in Table 4. 
Table 1. Distance from the river and water table fluctuation correlation analysis with DIC, DOC, $\mathrm{NH}_{4}{ }^{+}$and $\mathrm{NO}_{3}{ }^{-}$.

\begin{tabular}{|c|c|c|c|c|}
\hline \multirow{2}{*}{} & \multicolumn{2}{|c|}{ Distance from the river } & \multicolumn{2}{c|}{ Water table fluctuation } \\
\cline { 2 - 5 } & $\mathrm{r}$ & $\mathrm{p}$-value & $\mathrm{r}$ & $\mathrm{p}$-value \\
\hline $\mathrm{DIC}$ & -0.433 & $<0.001$ & 0.028 & $\mathrm{NS}$ \\
\hline $\mathrm{DOC}$ & -0.068 & $\mathrm{NS}$ & -0.050 & $\mathrm{NS}$ \\
\hline $\mathrm{NH}_{4}{ }^{-}$ & 0.055 & $\mathrm{NS}$ & -0.141 & $\mathrm{NS}$ \\
\hline $\mathrm{NO}_{3}{ }^{-}$ & -0.214 & 0.009 & -0.184 & $\mathrm{NS}$ \\
\hline
\end{tabular}

Table 2. One-way ANOVA and Tukey test results test results for DIC, DOC, $\mathrm{NH}_{4}{ }^{+}, \mathrm{NO}_{3}{ }^{-}$and $\mathrm{NH}_{4}{ }^{+}-\mathrm{NO}_{3}{ }^{-}$as the dependent variables and vegetation community. Letters in parentheses represent significant differences from Tukey tests.

\begin{tabular}{|c|c|c|c|c|c|}
\hline $\begin{array}{c}\text { vegetation } \\
\text { community }\end{array}$ & p-value & Riparian area & Edge & $\begin{array}{c}\text { Pinus banksiana } \\
\text { plantation }\end{array}$ & $\begin{array}{c}\text { Mature } \\
\text { Picea-Larix-Pinus } \\
\text { stand }\end{array}$ \\
\hline $\mathrm{DIC}(\mathrm{mg} / \mathrm{L})$ & $<0.001$ & $13.31(\mathrm{a})$ & $6.21(\mathrm{~b})$ & $1.96(\mathrm{c})$ & $1.69(\mathrm{c})$ \\
\hline $\mathrm{DOC}(\mathrm{mg} / \mathrm{L})$ & $<0.001$ & $27.40(\mathrm{ab})$ & $23.46(\mathrm{~b})$ & $33.85(\mathrm{a})$ & $27.61(\mathrm{ab})$ \\
\hline $\mathrm{NH}_{4}{ }^{-}(\mathrm{ppm})$ & $\mathrm{NS}$ & 0.11 & 0.07 & 0.13 & 0.14 \\
\hline $\mathrm{NO}_{3}{ }^{-}(\mathrm{ppm})$ & $<0.001$ & $0.21(\mathrm{a})$ & $0.06(\mathrm{~b})$ & $0.05(\mathrm{~b})$ & $0.07(\mathrm{~b})$ \\
\hline $\mathrm{NH}_{4}{ }^{-}-\mathrm{NO}_{3}^{-}$ & $<0.001$ & $-0.10(\mathrm{~b})$ & $-0.02(\mathrm{ab})$ & $0.07(\mathrm{a})$ & $0.07(\mathrm{a})$ \\
\hline
\end{tabular}


Table 3. Canonical correspondence analysis results - bi-plot scores. Vegetation abbreviations in Table 4.

\begin{tabular}{|l|r|r|}
\hline & \multicolumn{1}{|c|}{ Axis 1 } & \multicolumn{1}{c|}{ Axis 2 } \\
\hline DIC & 1.026 & 0.003 \\
DOC & -0.157 & 0.000 \\
NH4 & -0.195 & 0.400 \\
NO3 & 0.245 & -0.550 \\
\hline WTF & -0.073 & 0.354 \\
O AR & 0.860 & 0.046 \\
O PB & -0.306 & 0.023 \\
O PM & -0.419 & 0.142 \\
O AI & 0.797 & 0.224 \\
O PG & 0.019 & -0.216 \\
O LL & -0.207 & 0.234 \\
U AR & -0.316 & -0.037 \\
U PM & -0.318 & 0.232 \\
U AI & 0.754 & -0.251 \\
U PG & -0.325 & -0.169 \\
U LL & -0.211 & 0.022 \\
U CF & 0.866 & 0.033 \\
U PS & 0.015 & 0.007 \\
U RH & -0.207 & -0.116 \\
U VA & -0.073 & -0.292 \\
U KP & -0.038 & -0.165 \\
U VC & -0.418 & 0.166 \\
U AM & 0.659 & 0.165 \\
U BP & 0.213 & -0.017 \\
U CHC & -0.184 & 0.183 \\
U LG & -0.477 & 0.283 \\
U D & -0.170 & -0.112 \\
G AI & 0.418 & -0.291 \\
G AM & 0.544 & -0.182 \\
G BP & 0.462 & 0.106 \\
\hline
\end{tabular}

\begin{tabular}{|l|r|r|}
\hline & \multicolumn{1}{|c|}{ Axis 1 } & \multicolumn{1}{c|}{ Axis 2 } \\
\hline G CC & 0.161 & -0.340 \\
G CHC & -0.040 & -0.341 \\
G C & -0.031 & -0.216 \\
G CR & -0.243 & 0.038 \\
G CT & -0.514 & 0.174 \\
G COC & -0.397 & -0.234 \\
G DC & -0.134 & 0.343 \\
G D & -0.228 & 0.165 \\
G FV & -0.222 & -0.372 \\
G ER & -0.038 & -0.165 \\
G GB & 0.871 & 0.019 \\
G GH & -0.364 & -0.033 \\
G IV & 0.253 & -0.369 \\
G KP & -0.107 & -0.346 \\
G LG & -0.153 & -0.148 \\
G MC & -0.396 & -0.428 \\
G OS & 0.733 & 0.162 \\
G P & -0.098 & -0.447 \\
G RH & 0.643 & 0.002 \\
G S & 0.300 & 0.252 \\
G SP & 0.706 & 0.167 \\
G TD & 0.418 & -0.291 \\
G VA & -0.565 & 0.112 \\
G VC & -0.038 & -0.165 \\
G V & 0.686 & -0.250 \\
B DI & -0.396 & 0.282 \\
B PL & -0.116 & 0.462 \\
B PO & -0.248 & 0.422 \\
B SP & -0.430 & 0.107 \\
\hline
\end{tabular}


Table 4. Vegetation species abbreviations

\begin{tabular}{|ll|}
\hline Overstory \\
\hline O Acer rubrum & O AR \\
\hline O Alnus incana & O AI \\
\hline O Larix laricina & O LL \\
\hline O Pinus banksiana & O PB \\
\hline O Pinus glauca & O PG \\
\hline O Pinus mariana & O PM \\
\hline
\end{tabular}

\begin{tabular}{|ll|}
\hline Understory & O AR \\
\hline U Acer rubrum & U AI \\
\hline U Alnus incana & U AM \\
\hline U Aronia melanocarpa & O BP \\
\hline U Betula pumila & U CF \\
\hline U Chamaedaphne calyculata & U CHC \\
\hline U Cornus foemina & U D \\
\hline U Dryopteris spp. & U KP \\
\hline U Kalmia polifolia & U LL \\
\hline U Larix laricina & U LG \\
\hline U Ledum groenlandicum & U PG \\
\hline U Pinus glauca & U PM \\
\hline U Pinus mariana & U PS \\
\hline U Prunus serotina & U RH \\
\hline U Rubus hispidus & U VA \\
\hline U Vaccinium angustifolium & U VC \\
\hline U Vibernum cassinoides & \\
\hline
\end{tabular}

\begin{tabular}{|ll|}
\hline Bryophytes \\
\hline B Dicranum spp. & B DI \\
\hline B Pleurozium spp. & B PL \\
\hline B Polytrichum spp. & B PO \\
\hline B Sphagnum spp. & B SP \\
\hline
\end{tabular}

\begin{tabular}{|ll|}
\hline Groundcover & \\
\hline G Aronia melanocarpa & G AM \\
\hline G Alnus incana & G AI \\
\hline G Betula pumila & G BP \\
\hline G Calamagrostis canadensis & G CC \\
\hline G Carex spp. & G C \\
\hline G Chamaedaphne calyculata & G CHC \\
\hline G Cladina rangiferina & G CR \\
\hline G Coptis trifolia & G CT \\
\hline G Cornus canadensis & G COC \\
\hline G Deschampsia cespitosa & G DC \\
\hline G Dryopteris spp. & G D \\
\hline G Epigaea repens & G ER \\
\hline G Fragaria virginiana & G FV \\
\hline G Galium boreale & G GB \\
\hline G Gaultheria hispidula & G GH \\
\hline G Iris versicolor & G IV \\
\hline G Kalmia polifolia & G KP \\
\hline G Ledum groenlandicum & G LG \\
\hline G Mianthemum canadensis & G MC \\
\hline G Onoclea sensibilis & G OS \\
\hline G Potamogeton spp. & G P \\
\hline G Rubus hispidus & G RH \\
\hline G Solidago spp. & G S \\
\hline G Spartina pectinata & G SP \\
\hline G Thalictrum dasycarpum & G TD \\
\hline G Vaccinium angustifolium & G VA \\
\hline G Vibernum cassinoides & G VC \\
\hline G Viola spp. & G V \\
\hline
\end{tabular}




\section{APPENDIX 1: Carbon, nitrogen and water table Data}

\begin{tabular}{|c|c|c|c|c|c|c|c|c|c|c|}
\hline Month & Year & Transect & Station & Depth & TDC & DIC & DOC & NH4 & NO3 & $\begin{array}{l}\text { Water Table } \\
\text { Fluctuations }\end{array}$ \\
\hline 6 & 2002 & 1 & 1 & 50 & 31.44 & 11.89 & 19.55 & 0.07195 & 0.5921 & \\
\hline 6 & 2002 & 1 & 1 & 100 & 23.45 & 1.54 & 21.91 & & & \\
\hline 6 & 2002 & 1 & 1 & 25 & 32.15 & 5.22 & 26.93 & 0.0001 & 0.0214 & \\
\hline 6 & 2002 & 1 & 2 & 50 & 26.1 & 6.381 & 19.719 & 0.0001 & 0.0115 & \\
\hline 6 & 2002 & 1 & 2 & 100 & 22.42 & 2.707 & 19.713 & 0.0001 & 0.0379 & \\
\hline 6 & 2002 & 1 & 2 & 25 & 36.45 & 9.87 & 26.58 & 0.0001 & 0.0213 & \\
\hline 6 & 2002 & 1 & 3 & 50 & 27.56 & 1.32 & 26.24 & & & \\
\hline 6 & 2002 & 1 & 3 & 100 & 25.66 & 0.65 & 25.01 & & & \\
\hline 6 & 2002 & 1 & 3 & 25 & 28.65 & 0.24 & 28.41 & 0.0001 & 0.0142 & \\
\hline 6 & 2002 & 1 & 4 & 50 & 29.13 & 0.218 & 28.912 & 0.0001 & 0.0082 & \\
\hline 6 & 2002 & 1 & 4 & 100 & 20.56 & 1.175 & 19.385 & 0.0001 & 0.3828 & \\
\hline 6 & 2002 & 1 & 4 & 25 & 32.45 & 0.22 & 32.23 & 0.0001 & 0.2541 & \\
\hline 6 & 2002 & 1 & 5 & 50 & 12.29 & 0.59 & 11.7 & 0.0001 & 0.0831 & \\
\hline 6 & 2002 & 1 & 5 & 100 & 11.11 & 1.021 & 10.089 & 0.1545 & 0.093 & \\
\hline 6 & 2002 & 1 & 5 & 25 & 10.56 & 0.45 & 10.11 & 0.0135 & 0.5511 & \\
\hline 6 & 2002 & 1 & 6 & 50 & 16.53 & 1.777 & 14.753 & 0.1216 & 0.0856 & \\
\hline 6 & 2002 & 1 & 6 & 100 & 25.1 & 1.232 & 23.868 & 0.0001 & 0.0149 & \\
\hline 6 & 2002 & 1 & 6 & 25 & 26.44 & 0.29 & 26.15 & 0.0561 & 0.0125 & \\
\hline 6 & 2002 & 2 & 1 & 50 & 33.02 & 12.55 & 20.47 & 0.16595 & 0.0208 & \\
\hline 6 & 2002 & 2 & 1 & 100 & 32.78 & 12.55 & 20.23 & 0.0001 & 0.0911 & \\
\hline 6 & 2002 & 2 & 1 & 25 & 46.58 & 18.45 & 28.13 & 0.0001 & 0.0326 & \\
\hline 6 & 2002 & 2 & 2 & 50 & 16.22 & 1.553 & 14.667 & 0.0001 & 0.0081 & \\
\hline 6 & 2002 & 2 & 2 & 100 & 20.83 & 4.855 & 15.975 & 0.03835 & 0.1074 & \\
\hline 6 & 2002 & 2 & 2 & 25 & 26.33 & 7.46 & 18.87 & 0.0215 & 0.0123 & \\
\hline 6 & 2002 & 2 & 3 & 50 & 49.21 & 1.304 & 47.906 & 0.17975 & 0.0163 & \\
\hline 6 & 2002 & 2 & 3 & 100 & 21.38 & 2.248 & 19.132 & 0.69915 & 0.0246 & \\
\hline 6 & 2002 & 2 & 3 & 25 & 25.65 & 1.24 & 24.41 & 0.215 & 0.1241 & \\
\hline 6 & 2002 & 2 & 4 & 50 & 16 & 0.787 & 15.213 & 0.0001 & 0.0129 & \\
\hline 6 & 2002 & 2 & 5 & 50 & 11.53 & 0.442 & 11.088 & 0.01275 & 0.0233 & \\
\hline 6 & 2002 & 2 & 5 & 100 & 34.11 & 1.14 & 32.97 & 0.0314 & 0.012 & \\
\hline 6 & 2002 & 2 & 5 & 25 & 68.54 & 1.1 & 67.44 & 0.0231 & 0.547 & \\
\hline 6 & 2002 & 2 & 6 & 50 & 21.09 & 1.659 & 19.431 & 0.19525 & 0.0369 & \\
\hline 6 & 2002 & 2 & 6 & 100 & 16.46 & 0.69 & 15.77 & 0.0001 & 0.1915 & \\
\hline 6 & 2002 & 2 & 6 & 25 & 38.44 & 0.55 & 37.89 & 0.321 & 0.0089 & \\
\hline 6 & 2002 & 3 & 1 & 50 & 51.35 & 11.35 & 40 & 0.0001 & 0.9573 & \\
\hline 6 & 2002 & 3 & 1 & 100 & 32.3 & 5.738 & 26.562 & 0.2963 & 0.609 & \\
\hline 6 & 2002 & 3 & 1 & 25 & 34.1 & 3.34 & 30.76 & 0.3254 & 0.871 & \\
\hline 6 & 2002 & 3 & 3 & 100 & 19.77 & 1 & 18.77 & 0.125 & 0.0354 & \\
\hline 6 & 2002 & 3 & 3 & 25 & 57.35 & 0.26 & 57.09 & 0.0444 & 0.0129 & \\
\hline 6 & 2002 & 3 & 4 & 50 & 65.82 & 0.229 & 65.591 & 0.02905 & 0.012 & \\
\hline 6 & 2002 & 3 & 4 & 100 & 48.76 & 0.53 & 48.23 & 0.0098 & 0.0369 & \\
\hline 6 & 2002 & 3 & 4 & 25 & 61.25 & 1.29 & 59.96 & 0.0001 & 0.0325 & \\
\hline 6 & 2002 & 3 & 5 & 50 & 23.22 & 0.156 & 23.064 & 0.1658 & 0.0994 & \\
\hline 6 & 2002 & 3 & 5 & 100 & 51.83 & 0.517 & 51.313 & 0.02425 & 0.0203 & \\
\hline 6 & 2002 & 3 & 5 & 25 & 51.03 & 1.05 & 49.98 & 0.1243 & 0.1241 & \\
\hline 6 & 2002 & 3 & 6 & 50 & 32.7 & 0.766 & 31.934 & 0.24375 & 0.0236 & \\
\hline 6 & 2002 & 3 & 6 & 100 & 37.98 & 0.154 & 37.826 & 0.0124 & 0.0325 & \\
\hline 6 & 2002 & 3 & 6 & 25 & 44.65 & 0.248 & 44.402 & 0.122 & 0.0149 & \\
\hline 7 & 2002 & 1 & 1 & 50 & 48.65 & 29.56 & 19.09 & 0.07195 & 0.5921 & 20 \\
\hline 7 & 2002 & 1 & 1 & 100 & 36.45 & 13.25 & 23.2 & 0.0001 & 0.2354 & 20 \\
\hline 7 & 2002 & 1 & 1 & 25 & 84.65 & 3.45 & 81.2 & 0.1678 & 0.3489 & 20 \\
\hline
\end{tabular}


Water Table

\begin{tabular}{|c|c|c|c|c|c|c|c|c|c|c|}
\hline Month & Year & Transect & Station & Depth & TDC & DIC & DOC & NH4 & NO3 & Fluctuations \\
\hline 7 & 2002 & 1 & 2 & 50 & 22.43 & 3.21 & 19.22 & 0.0001 & 0.0115 & 30 \\
\hline 7 & 2002 & 1 & 2 & 100 & 19.35 & 1.658 & 17.692 & 0.0001 & 0.0379 & 30 \\
\hline 7 & 2002 & 1 & 2 & 25 & 22.89 & 4.351 & 18.539 & 0.0001 & 0.0264 & 30 \\
\hline 7 & 2002 & 1 & 3 & 50 & 48.34 & 0.659 & 47.681 & 0.0235 & 0.0123 & 50 \\
\hline 7 & 2002 & 1 & 3 & 100 & 43.25 & 0.488 & 42.762 & 0.0658 & 0.0142 & 50 \\
\hline 7 & 2002 & 1 & 3 & 25 & 49.65 & 0.358 & 49.292 & 0.0458 & 0.0245 & 50 \\
\hline 7 & 2002 & 1 & 4 & 50 & 29.34 & 1.375 & 27.965 & 0.0001 & 0.0082 & 20 \\
\hline 7 & 2002 & 1 & 4 & 100 & 38.45 & 0.554 & 37.896 & 0.0001 & 0.3828 & 20 \\
\hline 7 & 2002 & 1 & 4 & 25 & 36.45 & 9.764 & 26.686 & 0.0124 & 0.2415 & 20 \\
\hline 7 & 2002 & 1 & 5 & 50 & 16.52 & 1.004 & 15.516 & 0.0001 & 0.0831 & 30 \\
\hline 7 & 2002 & 1 & 5 & 100 & 14.38 & 2.671 & 11.709 & 0.1545 & 0.093 & 30 \\
\hline 7 & 2002 & 1 & 5 & 25 & 12.34 & 0.356 & 11.984 & 0.0248 & 0.0354 & 30 \\
\hline 7 & 2002 & 1 & 6 & 50 & 10.24 & 1.552 & 8.688 & 0.1216 & 0.0856 & 25 \\
\hline 7 & 2002 & 1 & 6 & 100 & 20.64 & 0.694 & 19.946 & 0.0001 & 0.0149 & 25 \\
\hline 7 & 2002 & 1 & 6 & 25 & 35.32 & 0.287 & 35.033 & 0.1687 & 0.0956 & 25 \\
\hline 7 & 2002 & 2 & 1 & 50 & 46.88 & 23.65 & 23.23 & 0.0001 & 0.1543 & 27 \\
\hline 7 & 2002 & 2 & 1 & 100 & 44.66 & 13.58 & 31.08 & 0.0354 & 0.07458 & 27 \\
\hline 7 & 2002 & 2 & 1 & 25 & 70.65 & 35.66 & 34.99 & 0.0001 & 0.5452 & 27 \\
\hline 7 & 2002 & 2 & 2 & 50 & 21.36 & 5.39 & 15.97 & 0.03835 & 0.1074 & 20 \\
\hline 7 & 2002 & 2 & 2 & 100 & 19.87 & 1.883 & 17.987 & 0.0687 & 0.167 & 20 \\
\hline 7 & 2002 & 2 & 2 & 25 & 25.33 & 4.972 & 20.358 & 0.1542 & 0.0988 & 20 \\
\hline 7 & 2002 & 2 & 3 & 50 & 58.64 & 0.773 & 57.867 & 0.7712 & 0.0354 & 42 \\
\hline 7 & 2002 & 2 & 3 & 100 & 28.46 & 0.348 & 28.112 & 0.4591 & 0.0261 & 42 \\
\hline 7 & 2002 & 2 & 3 & 25 & 59.37 & 1.234 & 58.136 & 0.0001 & 0.02154 & 42 \\
\hline 7 & 2002 & 2 & 4 & 50 & 42.63 & 0.167 & 42.463 & 0.6874 & 0.0351 & 10 \\
\hline 7 & 2002 & 2 & 4 & 100 & 40.02 & 0.394 & 39.626 & 0.4581 & 0.0645 & 10 \\
\hline 7 & 2002 & 2 & 4 & 25 & 54.35 & 0.459 & 53.891 & 0.0124 & 0.0351 & 10 \\
\hline 7 & 2002 & 2 & 5 & 50 & 17.38 & 0.178 & 17.202 & 0.4512 & 0.09871 & 55 \\
\hline 7 & 2002 & 2 & 5 & 100 & 15.31 & 1.591 & 13.719 & 0.2354 & 0.0311 & 55 \\
\hline 7 & 2002 & 2 & 5 & 25 & 79.8 & 1.652 & 78.148 & 0.2468 & 0.0665 & 55 \\
\hline 7 & 2002 & 2 & 6 & 50 & 19.87 & 0.267 & 19.603 & 0.0215 & 0.1354 & 38 \\
\hline 7 & 2002 & 2 & 6 & 100 & 18.99 & 0.189 & 18.801 & 0.0874 & 0.0522 & 38 \\
\hline 7 & 2002 & 2 & 6 & 25 & 54.39 & 1 & 53.39 & 0.0111 & 0.4685 & 38 \\
\hline 7 & 2002 & 3 & 1 & 50 & 39.84 & 5.461 & 34.379 & 0.3265 & 0.1248 & 50 \\
\hline 7 & 2002 & 3 & 1 & 100 & 23.67 & 0.157 & 23.513 & 0.3264 & 0.0325 & 50 \\
\hline 7 & 2002 & 3 & 1 & 25 & 53.22 & 0.502 & 52.718 & 0.0321 & 0.0668 & 50 \\
\hline 7 & 2002 & 3 & 2 & 50 & 24.59 & 3.468 & 21.122 & 0.0125 & 0.3251 & 31 \\
\hline 7 & 2002 & 3 & 2 & 25 & 66.45 & 7.91 & 58.54 & 0.1235 & 0.321 & 31 \\
\hline 7 & 2002 & 3 & 3 & 50 & 39.01 & 0.198 & 38.812 & 0.1345 & 0.2365 & 25 \\
\hline 7 & 2002 & 3 & 3 & 100 & 29.68 & 1.358 & 28.322 & 0.0314 & 0.1292 & 25 \\
\hline 7 & 2002 & 3 & 3 & 25 & 55.9 & 0.975 & 54.925 & 0.0325 & 0.0112 & 25 \\
\hline 7 & 2002 & 3 & 4 & 50 & 41.35 & 0.387 & 40.963 & 0.0326 & 0.0114 & 20 \\
\hline 7 & 2002 & 3 & 4 & 100 & 33.41 & 0.325 & 33.085 & 0.0215 & 0.0214 & 20 \\
\hline 7 & 2002 & 3 & 4 & 25 & 72.44 & 1.384 & 71.056 & 0.0356 & 0.0441 & 20 \\
\hline 7 & 2002 & 3 & 5 & 50 & 70.54 & 0.887 & 69.653 & 0.1984 & 0.1243 & 43 \\
\hline 7 & 2002 & 3 & 5 & 100 & 29.78 & 0.447 & 29.333 & 0.0325 & 0.01 & 43 \\
\hline 7 & 2002 & 3 & 5 & 25 & 95.33 & 0.146 & 95.184 & 0.235 & 0.1132 & 43 \\
\hline 7 & 2002 & 3 & 6 & 50 & 39.7 & 0.11 & 39.59 & 0.24375 & 0.0236 & 38 \\
\hline 7 & 2002 & 3 & 6 & 100 & 21.64 & 0.956 & 20.684 & 0.1243 & 0.0354 & 38 \\
\hline 7 & 2002 & 3 & 6 & 25 & 50.65 & 0.334 & 50.316 & 0.3325 & 0.1246 & 38 \\
\hline 8 & 2001 & 1 & 1 & 50 & 29.2 & 10.29 & 18.91 & & & 5 \\
\hline 8 & 2001 & 1 & 1 & 100 & 16.22 & 4.826 & 11.394 & & & 5 \\
\hline 8 & 2002 & 1 & 1 & 50 & 47.53 & 26.24 & 21.29 & 0.15095 & 0.2509 & 0 \\
\hline 8 & 2002 & 1 & 1 & 100 & 34.86 & 14.91 & 19.95 & 0.0425 & 0.2923 & 0 \\
\hline
\end{tabular}


Water Table

Month Year Transect Station Depth TDC DIC DOC NH4 NO3 Fluctuations

\begin{tabular}{|c|c|c|c|c|c|c|c|c|c|c|}
\hline 8 & 2002 & 1 & 1 & 25 & 85.71 & 0.37 & 85.34 & 0.0683 & 0.0229 & 0 \\
\hline 8 & 2001 & 1 & 2 & 50 & 30.08 & 11.65 & 18.43 & & & 10 \\
\hline 8 & 2001 & 1 & 2 & 100 & 15.29 & 0.628 & 14.662 & & & 10 \\
\hline 8 & 2002 & 1 & 2 & 50 & 23.57 & 2.116 & 21.454 & 0.0001 & 0.0061 & 10 \\
\hline 8 & 2002 & 1 & 2 & 100 & 25.22 & 1.624 & 23.596 & 0.0001 & 0.029 & 10 \\
\hline 8 & 2002 & 1 & 2 & 25 & 23.49 & 2.229 & 21.261 & 0.0001 & 0.0203 & 10 \\
\hline 8 & 2001 & 1 & 3 & 50 & 31.55 & 8.43 & 23.12 & & & 15 \\
\hline 8 & 2001 & 1 & 3 & 100 & 19.99 & 1.026 & 18.964 & & & 15 \\
\hline 8 & 2002 & 1 & 3 & 50 & 53.75 & 1.442 & 52.308 & 0.1884 & 0.0303 & 5 \\
\hline 8 & 2002 & 1 & 3 & 100 & 38.79 & 0.579 & 38.211 & 0.0986 & 0.0314 & 5 \\
\hline 8 & 2002 & 1 & 3 & 25 & 50.62 & 0.472 & 50.148 & 0.0032 & 0.0282 & 5 \\
\hline 8 & 2001 & 1 & 4 & 50 & 35.97 & 8.769 & 27.201 & & & 0 \\
\hline 8 & 2001 & 1 & 4 & 100 & 22.99 & 1.45 & 21.54 & & & 0 \\
\hline 8 & 2002 & 1 & 4 & 50 & 23.57 & 2.443 & 21.127 & 0.0001 & 0.0336 & 5 \\
\hline 8 & 2002 & 1 & 4 & 100 & 41.52 & 1.579 & 39.941 & 0.10245 & 0.0217 & 5 \\
\hline 8 & 2002 & 1 & 4 & 25 & 30.16 & 13.33 & 16.83 & 0.00235 & 0.0325 & 5 \\
\hline 8 & 2001 & 1 & 5 & 50 & 26.29 & 6.875 & 19.415 & & & 5 \\
\hline 8 & 2001 & 1 & 5 & 100 & 5.53 & 0.134 & 5.396 & & & 5 \\
\hline 8 & 2002 & 1 & 5 & 50 & 15.55 & 1.525 & 14.025 & 0.0001 & 0.0034 & 5 \\
\hline 8 & 2002 & 1 & 5 & 100 & 14.32 & 3.611 & 10.709 & 0.3674 & 0.1176 & 5 \\
\hline 8 & 2002 & 1 & 5 & 25 & 10.35 & 1.22 & 9.13 & 0.0001 & 0.0054 & 5 \\
\hline 8 & 2001 & 1 & 6 & 50 & 41.15 & 4.18 & 36.97 & & & 5 \\
\hline 8 & 2001 & 1 & 6 & 100 & 17.79 & 6.5 & 11.29 & & & 5 \\
\hline 8 & 2002 & 1 & 6 & 50 & 15.82 & 1.834 & 13.986 & 0.06535 & 0.0678 & 5 \\
\hline 8 & 2002 & 1 & 6 & 100 & 27.8 & 1.118 & 26.682 & 0.1654 & 0.0163 & 5 \\
\hline 8 & 2002 & 1 & 6 & 25 & 29.87 & 0.358 & 29.512 & 0.0354 & 0.0234 & 5 \\
\hline 8 & 2001 & 2 & 1 & 50 & 54.68 & 22.45 & 32.23 & & & 15 \\
\hline 8 & 2001 & 2 & 1 & 100 & 40.3 & 16.99 & 23.31 & & & 15 \\
\hline 8 & 2002 & 2 & 1 & 50 & 41.76 & 22.13 & 19.63 & 0.1698 & 0.0808 & 22 \\
\hline 8 & 2002 & 2 & 1 & 100 & 46.16 & 23.37 & 22.79 & 0.1292 & 0.0911 & 22 \\
\hline 8 & 2002 & 2 & 1 & 25 & 74.28 & 31.23 & 43.05 & 0.39095 & 0.0306 & 22 \\
\hline 8 & 2001 & 2 & 2 & 50 & 37.68 & 13.99 & 23.69 & & & $\Gamma$ \\
\hline 8 & 2001 & 2 & 2 & 100 & 29.2 & 10.29 & 18.91 & & & J \\
\hline 8 & 2002 & 2 & 2 & 50 & 18.61 & 2.382 & 16.228 & 0.1744 & 0.018 & 5 \\
\hline 8 & 2002 & 2 & 2 & 100 & 20.16 & 1.908 & 18.252 & 0.2392 & 0.0496 & 5 \\
\hline 8 & 2002 & 2 & 2 & 25 & 24.41 & 2.022 & 22.388 & 0.1006 & 0.0243 & 5 \\
\hline 8 & 2001 & 2 & 3 & 50 & 16.22 & 4.826 & 11.394 & & & 25 \\
\hline 8 & 2001 & 2 & 3 & 100 & 30.08 & 11.65 & 18.43 & & & 25 \\
\hline 8 & 2002 & 2 & 3 & 50 & 56.83 & 0.667 & 56.163 & 0.0694 & 0.0118 & 63 \\
\hline 8 & 2002 & 2 & 3 & 100 & 26.92 & 0.625 & 26.295 & 0.22165 & 0.0189 & 63 \\
\hline 8 & 2002 & 2 & 3 & 25 & 52.87 & 0.993 & 51.877 & 0.0124 & 0.0063 & 63 \\
\hline 8 & 2001 & 2 & 4 & 50 & 15.29 & 0.628 & 14.662 & & & 0 \\
\hline 8 & 2001 & 2 & 4 & 100 & 31.55 & 8.43 & 23.12 & & & 0 \\
\hline 8 & 2002 & 2 & 4 & 50 & 41.45 & 0.893 & 40.557 & 0.05365 & 0.0178 & 10 \\
\hline 8 & 2002 & 2 & 4 & 100 & 61.98 & 4.44 & 57.54 & 0.2918 & 0.0374 & 10 \\
\hline 8 & 2002 & 2 & 4 & 25 & 47.2 & 0.529 & 46.671 & 0.05055 & 0.0239 & 10 \\
\hline 8 & 2001 & 2 & 5 & 50 & 19.99 & 1.026 & 18.964 & & & 2 \\
\hline 8 & 2001 & 2 & 5 & 100 & 35.97 & 8.769 & 27.201 & & & 20 \\
\hline 8 & 2002 & 2 & 5 & 50 & 10.14 & 0.493 & 9.647 & 0.05545 & 0.0479 & 30 \\
\hline 8 & 2002 & 2 & 5 & 100 & 17.09 & 1.655 & 15.435 & 0.001 & 0.0042 & 30 \\
\hline 8 & 2002 & 2 & 5 & 25 & 78.1 & 1.283 & 76.817 & 0.02075 & 0.0107 & 3 \\
\hline 8 & 2001 & 2 & 6 & 50 & 22.99 & 1.45 & 21.54 & & & 2 \\
\hline 8 & 2001 & 2 & 6 & 100 & 26.29 & 6.875 & 19.415 & & & 2 \\
\hline 8 & 2002 & 2 & 6 & 50 & 17.44 & 0.504 & 16.936 & 0.0001 & 0.0118 & 3 \\
\hline
\end{tabular}


Water Table

\begin{tabular}{|c|c|c|c|c|c|c|c|c|c|c|}
\hline Month & Year & Transect & Station & Depth & TDC & DIC & DOC & NH4 & NO3 & Fluctuations \\
\hline 8 & 2002 & 2 & 6 & 100 & 19.65 & 0.553 & 19.097 & 0.1068 & 0.0557 & 3 \\
\hline 8 & 2002 & 2 & 6 & 25 & 49.73 & 1.031 & 48.699 & 0.0001 & 0.0074 & 3 \\
\hline 8 & 2001 & 3 & 1 & 50 & 5.53 & 0.134 & 5.396 & & & 15 \\
\hline 8 & 2001 & 3 & 1 & 100 & 41.15 & 4.18 & 36.97 & & & 15 \\
\hline 8 & 2002 & 3 & 1 & 100 & 26.01 & 0.494 & 25.516 & 0.29735 & 0.426 & 12 \\
\hline 8 & 2002 & 3 & 1 & 25 & 50.76 & 0.517 & 50.243 & 0.0683 & 0.0436 & 12 \\
\hline 8 & 2001 & 3 & 2 & 50 & 17.79 & 6.5 & 11.29 & & & 5 \\
\hline 8 & 2001 & 3 & 2 & 100 & 27.06 & 10.8 & 16.26 & & & 5 \\
\hline 8 & 2002 & 3 & 2 & 50 & 26.4 & 1.357 & 25.043 & 0.1094 & 0.0223 & 8 \\
\hline 8 & 2002 & 3 & 2 & 25 & 63.21 & 0.486 & 62.724 & 0.2848 & 0.0332 & 8 \\
\hline 8 & 2001 & 3 & 3 & 50 & 24.91 & 5.34 & 19.57 & & & 0 \\
\hline 8 & 2001 & 3 & 3 & 100 & 37.11 & 10.3 & 26.81 & & & 0 \\
\hline 8 & 2002 & 3 & 3 & 50 & 32.22 & 0.764 & 31.456 & 0.242 & 0.0277 & 15 \\
\hline 8 & 2002 & 3 & 3 & 100 & 23.79 & 1.874 & 21.916 & 0.1048 & 0.0349 & 15 \\
\hline 8 & 2002 & 3 & 3 & 25 & 51.01 & 0.374 & 50.636 & 0.00675 & 0.0046 & 15 \\
\hline 8 & 2001 & 3 & 4 & 50 & 15.28 & 0.519 & 14.761 & & & 5 \\
\hline 8 & 2001 & 3 & 4 & 100 & 27.68 & 5.264 & 22.416 & & & 5 \\
\hline 8 & 2002 & 3 & 4 & 50 & 39.38 & 0.27 & 39.11 & 0.004 & 0.0098 & 5 \\
\hline 8 & 2002 & 3 & 4 & 100 & 37.97 & 0.276 & 37.694 & 0.0001 & 0.0138 & 5 \\
\hline 8 & 2002 & 3 & 4 & 25 & 69.24 & 1.245 & 67.995 & 0.0001 & 0.011 & 5 \\
\hline 8 & 2001 & 3 & 5 & 50 & 32.77 & 14.95 & 17.82 & & & 5 \\
\hline 8 & 2001 & 3 & 5 & 100 & 5.65 & 0.21 & 5.44 & & & 5 \\
\hline 8 & 2002 & 3 & 5 & 50 & 69.53 & 0.341 & 69.189 & 0.1114 & 0.0164 & 13 \\
\hline 8 & 2002 & 3 & 5 & 100 & 31.02 & 1.288 & 29.732 & 0.15055 & 0.0499 & 13 \\
\hline 8 & 2002 & 3 & 5 & 25 & 98.48 & 0.243 & 98.237 & & 0.0169 & 13 \\
\hline 8 & 2001 & 3 & 6 & 50 & 36.7 & 16.98 & 19.72 & & & 10 \\
\hline 8 & 2001 & 3 & 6 & 100 & 19.2 & 2.76 & 16.44 & & & 10 \\
\hline 8 & 2002 & 3 & 6 & 50 & 41.69 & 0.146 & 41.544 & 0.06935 & 0.0153 & 8 \\
\hline 8 & 2002 & 3 & 6 & 100 & 22 & 1.144 & 20.856 & 0.67835 & 0.0196 & 8 \\
\hline 8 & 2002 & 3 & 6 & 25 & 49.34 & 0.238 & 49.102 & 0.325 & 0.1224 & 8 \\
\hline 9 & 2001 & 1 & 1 & 50 & 22.14 & 14.65 & 7.49 & & & 30 \\
\hline 9 & 2001 & 1 & 1 & 50 & 37.87 & 26.22 & 11.65 & & & 30 \\
\hline 9 & 2001 & 1 & 1 & 100 & 14.01 & 3.13 & 10.88 & & & 30 \\
\hline 9 & 2001 & 1 & 1 & 100 & 18.74 & 3.64 & 15.1 & & & 30 \\
\hline 9 & 2002 & 1 & 1 & 50 & 51.38 & 33.46 & 17.92 & 0.1987 & 0.3541 & 15 \\
\hline 9 & 2002 & 1 & 1 & 100 & 39.88 & 21.45 & 18.43 & 0.114 & 0.3245 & 15 \\
\hline 9 & 2002 & 1 & 1 & 25 & 91.33 & 8.79 & 82.54 & 0.0541 & 0.0354 & 15 \\
\hline 9 & 2001 & 1 & 2 & 50 & 15.12 & 4.65 & 10.47 & & & 25 \\
\hline 9 & 2001 & 1 & 2 & 50 & 41.58 & 22.94 & 18.64 & & & 25 \\
\hline 9 & 2001 & 1 & 2 & 100 & 19.45 & 2.44 & 17.01 & & & 25 \\
\hline 9 & 2001 & 1 & 2 & 100 & 17.45 & 0.65 & 16.8 & & & 25 \\
\hline 9 & 2002 & 1 & 2 & 50 & 22.77 & 6.34 & 16.43 & 0.0001 & 0.045 & 14 \\
\hline 9 & 2002 & 1 & 2 & 100 & 20.33 & 0.642 & 19.688 & 0.0001 & 0.0654 & 14 \\
\hline 9 & 2002 & 1 & 2 & 25 & 29.88 & 6.37 & 23.51 & 0.0001 & 0.0325 & 14 \\
\hline 9 & 2001 & 1 & 3 & 50 & 8.23 & 0.34 & 7.89 & & & 50 \\
\hline 9 & 2001 & 1 & 3 & 50 & 26.66 & 1.76 & 24.9 & & & 50 \\
\hline 9 & 2001 & 1 & 3 & 100 & 7.55 & 0.21 & 7.34 & & & 50 \\
\hline 9 & 2001 & 1 & 3 & 100 & 28.17 & 0.61 & 27.56 & & & 50 \\
\hline 9 & 2002 & 1 & 3 & 50 & 57.99 & 1.355 & 56.635 & 0.1254 & 0.0125 & 14 \\
\hline 9 & 2002 & 1 & 3 & 100 & 39.55 & 0.441 & 39.109 & 0.1036 & 0.0321 & 14 \\
\hline 9 & 2002 & 1 & 3 & 25 & 54.36 & 2.115 & 52.245 & 0.0213 & 0.0221 & 14 \\
\hline 9 & 2001 & 1 & 4 & 50 & 14.41 & 0.5 & 13.91 & & & 50 \\
\hline 9 & 2001 & 1 & 4 & 50 & 14.82 & 0.68 & 14.14 & & & 50 \\
\hline 9 & 2001 & 1 & 4 & 100 & 15.45 & 0.41 & 15.04 & & & 50 \\
\hline
\end{tabular}


Water Table

\begin{tabular}{|c|c|c|c|c|c|c|c|c|c|c|}
\hline Month & Year & Transect & Station & Depth & TDC & DIC & DOC & NH4 & NO3 & Fluctuations \\
\hline 9 & 2001 & 1 & 4 & 100 & 11.35 & 0.99 & 10.36 & & & 50 \\
\hline 9 & 2002 & 1 & 4 & 50 & 23.88 & 3.456 & 20.424 & 0.0001 & 0.0321 & 31 \\
\hline 9 & 2002 & 1 & 4 & 100 & 34.52 & 0.687 & 33.833 & 0.125 & 0.0651 & 31 \\
\hline 9 & 2002 & 1 & 4 & 25 & 22.46 & 8.653 & 13.807 & 0.0001 & 0.0213 & 31 \\
\hline 9 & 2001 & 1 & 5 & 50 & 27.4 & 0.46 & 26.94 & & & 55 \\
\hline 9 & 2001 & 1 & 5 & 50 & 6.69 & 0.24 & 6.45 & & & 55 \\
\hline 9 & 2001 & 1 & 5 & 100 & 4.87 & 0.2 & 4.67 & & & 55 \\
\hline 9 & 2001 & 1 & 5 & 100 & 16.37 & 2.07 & 14.3 & & & 55 \\
\hline 9 & 2002 & 1 & 5 & 50 & 21.55 & 1.418 & 20.132 & 0.0001 & 0.0024 & 25 \\
\hline 9 & 2002 & 1 & 5 & 100 & 13.55 & 2.538 & 11.012 & 0.3251 & 0.1546 & 25 \\
\hline 9 & 2002 & 1 & 5 & 25 & 14.66 & 2.154 & 12.506 & 0.0001 & 0.0054 & 25 \\
\hline 9 & 2001 & 1 & 6 & 50 & 7.92 & 0.83 & 7.09 & & & 35 \\
\hline 9 & 2001 & 1 & 6 & 50 & 10.37 & 0.11 & 10.26 & & & 35 \\
\hline 9 & 2001 & 1 & 6 & 100 & 6.33 & 0.13 & 6.2 & & & 35 \\
\hline 9 & 2001 & 1 & 6 & 100 & 22.7 & 2.87 & 19.83 & & & 35 \\
\hline 9 & 2002 & 1 & 6 & 50 & 13.87 & 1.946 & 11.924 & 0.0365 & 0.0321 & 15 \\
\hline 9 & 2002 & 1 & 6 & 100 & 21.34 & 0.687 & 20.653 & 0.2145 & 0.0651 & 15 \\
\hline 9 & 2002 & 1 & 6 & 25 & 32.66 & 0.554 & 32.106 & 0.0211 & 0.231 & 15 \\
\hline 9 & 2001 & 2 & 1 & 50 & 40.48 & 27.61 & 12.87 & & & 40 \\
\hline 9 & 2001 & 2 & 1 & 100 & 37.29 & 24.74 & 12.55 & & & 40 \\
\hline 9 & 2002 & 2 & 1 & 50 & 29.67 & 12.45 & 17.22 & 0.0351 & 0.215 & 35 \\
\hline 9 & 2002 & 2 & 1 & 100 & 38.22 & 17.85 & 20.37 & 0.1879 & 0.1254 & 35 \\
\hline 9 & 2002 & 2 & 1 & 25 & 51.34 & 33.64 & 17.7 & 0.1223 & 0.1252 & 35 \\
\hline 9 & 2001 & 2 & 2 & 50 & 15.48 & 3.44 & 12.04 & & & 30 \\
\hline 9 & 2001 & 2 & 2 & 100 & 20.83 & 4.7 & 16.13 & & & 30 \\
\hline 9 & 2002 & 2 & 2 & 50 & 68.91 & 38.44 & 30.47 & 0.3264 & 0.1236 & 20 \\
\hline 9 & 2002 & 2 & 2 & 100 & 19.65 & 3.334 & 16.316 & 0.1587 & 0.0325 & 20 \\
\hline 9 & 2002 & 2 & 2 & 25 & 26.88 & 5.647 & 21.233 & 0.2135 & 0.0651 & 20 \\
\hline 9 & 2001 & 2 & 3 & 50 & 19.62 & 0.77 & 18.85 & & & 15 \\
\hline 9 & 2001 & 2 & 3 & 100 & 15.48 & 0.87 & 14.61 & & & 15 \\
\hline 9 & 2002 & 2 & 3 & 50 & 22.44 & 1.364 & 21.076 & 0.1235 & 0.0154 & 45 \\
\hline 9 & 2002 & 2 & 3 & 100 & 41.65 & 0.534 & 41.116 & 0.0455 & 0.0214 & 45 \\
\hline 9 & 2002 & 2 & 3 & 25 & 39.11 & 0.748 & 38.362 & 0.2035 & 0.0355 & 45 \\
\hline 9 & 2001 & 2 & 4 & 50 & 27.54 & 2.66 & 24.88 & & & 45 \\
\hline 9 & 2001 & 2 & 4 & 100 & 20.45 & 0.57 & 19.88 & & & 45 \\
\hline 9 & 2002 & 2 & 4 & 50 & 55.68 & 1.354 & 54.326 & 0.0245 & 0.0068 & 23 \\
\hline 9 & 2002 & 2 & 4 & 100 & 48.64 & 0.333 & 48.307 & 0.3254 & 0.0981 & 23 \\
\hline 9 & 2002 & 2 & 4 & 25 & 46.51 & 0.689 & 45.821 & 0.0325 & 0.0145 & 23 \\
\hline 9 & 2001 & 2 & 5 & 50 & 21.05 & 0.56 & 20.49 & & & 50 \\
\hline 9 & 2001 & 2 & 5 & 100 & 18.66 & 0.88 & 17.78 & & & 50 \\
\hline 9 & 2002 & 2 & 5 & 50 & 46.37 & 0.297 & 46.073 & 0.0456 & 0.0325 & 36 \\
\hline 9 & 2002 & 2 & 5 & 100 & 9.87 & 0.385 & 9.485 & 0.0598 & 0.347 & 36 \\
\hline 9 & 2002 & 2 & 5 & 25 & 19.87 & 1.355 & 18.515 & 0.0001 & 0.0001 & 36 \\
\hline 9 & 2001 & 2 & 6 & 50 & 12.62 & 0.59 & 12.03 & & & 40 \\
\hline 9 & 2001 & 2 & 6 & 100 & 20.07 & 2.3 & 17.77 & & & 40 \\
\hline 9 & 2002 & 2 & 6 & 50 & 64.35 & 2.384 & 61.966 & 0.0211 & 0.0214 & 11 \\
\hline 9 & 2002 & 2 & 6 & 100 & 19.62 & 1.325 & 18.295 & 0.0001 & 0.0112 & 11 \\
\hline 9 & 2002 & 2 & 6 & 25 & 24.33 & 0.159 & 24.171 & 0.124 & 0.0325 & 11 \\
\hline 9 & 2002 & 3 & 1 & 50 & 44.35 & 0.367 & 43.983 & 0.0001 & 0.0074 & 17 \\
\hline 9 & 2002 & 3 & 1 & 100 & 32.48 & 5.982 & 26.498 & 0.1654 & 0.0211 & 17 \\
\hline 9 & 2002 & 3 & 1 & 25 & 22.38 & 1.386 & 20.994 & & & 17 \\
\hline 9 & 2002 & 3 & 2 & 50 & 51.22 & 1.39 & 49.83 & & & 21 \\
\hline 9 & 2002 & 3 & 2 & 100 & 23.55 & 2.671 & 20.879 & & & 21 \\
\hline 9 & 2002 & 3 & 2 & 25 & 71.38 & 1.665 & 69.715 & & & 21 \\
\hline
\end{tabular}


Water Table

Month Year Transect Station Depth TDC DIC DOC NH4 NO3 Fluctuations

\begin{tabular}{|c|c|c|c|c|c|c|c|c|c|c|}
\hline 9 & 2002 & 3 & 3 & 50 & 31.88 & 0.249 & 31.631 & & & 24 \\
\hline 9 & 2002 & 3 & 3 & 100 & 21.34 & 0.667 & 20.673 & 0.23045 & 0.0194 & 24 \\
\hline 9 & 2002 & 3 & 3 & 25 & 53.28 & 0.948 & 52.332 & 0.01445 & 0.00855 & 24 \\
\hline 9 & 2002 & 3 & 4 & 50 & 41.33 & 0.198 & 41.132 & 0.06545 & 0.0498 & 43 \\
\hline 9 & 2002 & 3 & 4 & 100 & 34.58 & 0.144 & 34.436 & 0.7961 & 0.03905 & 43 \\
\hline 9 & 2002 & 3 & 4 & 25 & 72.64 & 2.334 & 70.306 & & 0.20045 & 43 \\
\hline 9 & 2002 & 3 & 5 & 50 & 64.25 & 0.569 & 63.681 & 0.83285 & 0.04995 & 26 \\
\hline 9 & 2002 & 3 & 5 & 100 & 35.11 & 1.652 & 33.458 & 0.96635 & 0.07705 & 26 \\
\hline 9 & 2002 & 3 & 5 & 25 & 91.54 & 0.133 & 91.407 & & & 26 \\
\hline 9 & 2002 & 3 & 6 & 50 & 40.32 & 0.548 & 39.772 & 0.2315 & 0.0104 & 24 \\
\hline 9 & 2002 & 3 & 6 & 100 & 21.6 & 1.065 & 20.535 & 0.1056 & 0.0118 & 24 \\
\hline 9 & 2002 & 3 & 6 & 25 & 38.44 & 1.044 & 37.396 & 0.7546 & 0.0325 & 24 \\
\hline 10 & 2001 & 1 & 1 & 50 & 27.3 & 11.77 & 15.53 & & & 40 \\
\hline 10 & 2001 & 1 & 1 & 100 & 17.33 & 3.245 & 14.085 & & & 40 \\
\hline 10 & 2002 & 1 & 1 & 50 & 58.34 & 39.55 & 18.79 & 0.1256 & 0.2153 & 25 \\
\hline 10 & 2002 & 1 & 1 & 100 & 41.23 & 22.35 & 18.88 & 0.0986 & 0.1986 & 25 \\
\hline 10 & 2002 & 1 & 1 & 25 & 87.33 & 10.65 & 76.68 & 0.0354 & 0.0214 & 25 \\
\hline 10 & 2001 & 1 & 2 & 50 & 31.31 & 9.44 & 21.87 & & & 30 \\
\hline 10 & 2001 & 1 & 2 & 100 & 14.21 & 0.294 & 13.916 & & & 30 \\
\hline 10 & 2002 & 1 & 2 & 50 & 22.67 & 8.54 & 14.13 & 0.0001 & 0.0124 & 24 \\
\hline 10 & 2002 & 1 & 2 & 100 & 19.64 & 0.225 & 19.415 & 0.0001 & 0.0325 & 24 \\
\hline 10 & 2002 & 1 & 2 & 25 & 35.64 & 14.51 & 21.13 & 0.0001 & 0.0149 & 24 \\
\hline 10 & 2001 & 1 & 3 & 50 & 30.67 & 5.33 & 25.34 & & & 60 \\
\hline 10 & 2001 & 1 & 3 & 100 & 18.93 & 0.611 & 18.319 & & & 60 \\
\hline 10 & 2002 & 1 & 3 & 50 & 55.67 & 2.65 & 53.02 & 0.0215 & 0.014 & 26 \\
\hline 10 & 2002 & 1 & 3 & 100 & 41.36 & 1.678 & 39.682 & 0.0987 & 0.0369 & 26 \\
\hline 10 & 2002 & 1 & 3 & 25 & 50.34 & 3.335 & 47.005 & 0.0125 & 0.0198 & 26 \\
\hline 10 & 2001 & 1 & 4 & 50 & 35.29 & 6.38 & 28.91 & & & 55 \\
\hline 10 & 2001 & 1 & 4 & 100 & 24.63 & 0.55 & 24.08 & & & 55 \\
\hline 10 & 2002 & 1 & 4 & 50 & 22.68 & 2.138 & 20.542 & 0.0001 & 0.0001 & 36 \\
\hline 10 & 2002 & 1 & 4 & 100 & 30.51 & 0.157 & 30.353 & 0.087 & 0.0001 & 36 \\
\hline 10 & 2002 & 1 & 4 & 25 & 21.65 & 4.559 & 17.091 & 0.0001 & 0.0123 & 36 \\
\hline 10 & 2001 & 1 & 5 & 50 & 24.34 & 2.11 & 22.23 & & & 50 \\
\hline 10 & 2001 & 1 & 5 & 100 & 5.61 & 0.248 & 5.362 & & & 50 \\
\hline 10 & 2002 & 1 & 5 & 50 & 19.64 & 0.354 & 19.286 & 0.0001 & 0.0045 & 35 \\
\hline 10 & 2002 & 1 & 5 & 100 & 12.59 & 1.599 & 10.991 & 0.1531 & 0.11 & 35 \\
\hline 10 & 2002 & 1 & 5 & 25 & 17.85 & 1.045 & 16.805 & 0.0001 & 0.0001 & 35 \\
\hline 10 & 2001 & 1 & 6 & 50 & 39.21 & 2.14 & 37.07 & & & 30 \\
\hline 10 & 2001 & 1 & 6 & 100 & 17.36 & 4.877 & 12.483 & & & 30 \\
\hline 10 & 2002 & 1 & 6 & 50 & 15.64 & 2.254 & 13.386 & 0.009 & 0.0001 & 20 \\
\hline 10 & 2002 & 1 & 6 & 100 & 14.65 & 0.224 & 14.426 & 0.1543 & 0.0452 & 20 \\
\hline 10 & 2002 & 1 & 6 & 25 & 30.54 & 0.458 & 30.082 & 0.015 & 0.1021 & 20 \\
\hline 10 & 2001 & 2 & 1 & 50 & 50.13 & 20.34 & 29.79 & & & 35 \\
\hline 10 & 2001 & 2 & 1 & 100 & 40.9 & 13.47 & 27.43 & & & 35 \\
\hline 10 & 2002 & 2 & 1 & 50 & 31.26 & 18.64 & 12.62 & 0.014 & 0.188 & 25 \\
\hline 10 & 2002 & 2 & 1 & 100 & 44.59 & 19.65 & 24.94 & 0.0897 & 0.099 & 25 \\
\hline 10 & 2002 & 2 & 1 & 25 & 51.33 & 35.27 & 16.06 & 0.114 & 0.1055 & 25 \\
\hline 10 & 2001 & 2 & 2 & 50 & 36.39 & 10.24 & 26.15 & & & 25 \\
\hline 10 & 2001 & 2 & 2 & 100 & 27.61 & 8.539 & 19.071 & & & 25 \\
\hline 10 & 2002 & 2 & 2 & 50 & 58.98 & 41.35 & 17.63 & 0.235 & 0.0948 & 5 \\
\hline 10 & 2002 & 2 & 2 & 100 & 26.34 & 6.84 & 19.5 & 0.0956 & 0.0224 & 5 \\
\hline 10 & 2002 & 2 & 2 & 25 & 34.55 & 8.91 & 25.64 & 0.2056 & 0.0455 & 5 \\
\hline 10 & 2001 & 2 & 3 & 50 & 15.39 & 2.14 & 13.25 & & & 40 \\
\hline 10 & 2001 & 2 & 3 & 100 & 32.53 & 9.507 & 23.023 & & & 40 \\
\hline
\end{tabular}


Water Table Month Year Transect Station Depth TDC DIC DOC NH4 NO3 Fluctuations

\begin{tabular}{|c|c|c|c|c|c|c|c|c|c|c|}
\hline 10 & 2002 & 2 & 3 & 50 & 25.88 & 0.352 & 25.528 & 0.114 & 0.0092 & 30 \\
\hline 10 & 2002 & 2 & 3 & 100 & 40.28 & 0.331 & 39.949 & 0.0142 & 0.0211 & 30 \\
\hline 10 & 2002 & 2 & 3 & 25 & 44.65 & 0.372 & 44.278 & 0.1546 & 0.0128 & 30 \\
\hline 10 & 2001 & 2 & 4 & 50 & 15.13 & 0.34 & 14.79 & & & 45 \\
\hline 10 & 2001 & 2 & 4 & 100 & 29.54 & 3.28 & 26.26 & & & 45 \\
\hline 10 & 2002 & 2 & 4 & 50 & 50.88 & 1.592 & 49.288 & 0.0001 & 0.0001 & 28 \\
\hline 10 & 2002 & 2 & 4 & 100 & 45.99 & 0.446 & 45.544 & 0.1598 & 0.102 & 28 \\
\hline 10 & 2002 & 2 & 4 & 25 & 49.87 & 1.658 & 48.212 & 0.0095 & 0.0078 & 28 \\
\hline 10 & 2001 & 2 & 5 & 50 & 21.39 & 0.21 & 21.18 & & & 45 \\
\hline 10 & 2001 & 2 & 5 & 100 & 31.39 & 7.341 & 24.049 & & & 45 \\
\hline 10 & 2002 & 2 & 5 & 50 & 41.65 & 1.592 & 40.058 & 0.056 & 0.021 & 36 \\
\hline 10 & 2002 & 2 & 5 & 100 & 10.47 & 0.781 & 9.689 & 0.0291 & 0.1143 & 36 \\
\hline 10 & 2002 & 2 & 5 & 25 & 23.34 & 2.215 & 21.125 & 0.0001 & 0.0001 & 36 \\
\hline 10 & 2001 & 2 & 6 & 50 & 22.49 & 0.55 & 21.94 & & & 30 \\
\hline 10 & 2001 & 2 & 6 & 100 & 24.87 & 3.388 & 21.482 & & & 30 \\
\hline 10 & 2002 & 2 & 6 & 50 & 57.66 & 1.752 & 55.908 & 0.0096 & 0.0087 & 16 \\
\hline 10 & 2002 & 2 & 6 & 100 & 21.05 & 1.059 & 19.991 & 0.0001 & 0.009 & 16 \\
\hline 10 & 2002 & 2 & 6 & 25 & 26.44 & 0.189 & 26.251 & 0.0543 & 0.0125 & 16 \\
\hline 10 & 2001 & 3 & 1 & 50 & 4.36 & 0.09 & 4.27 & & & 50 \\
\hline 10 & 2001 & 3 & 1 & 100 & 40.14 & 3.241 & 36.899 & & & 50 \\
\hline 10 & 2002 & 3 & 1 & 50 & 42.55 & 0.116 & 42.434 & 0.0001 & 0.0001 & 35 \\
\hline 10 & 2002 & 3 & 1 & 100 & 31.22 & 4.287 & 26.933 & 0.1561 & 0.0133 & 35 \\
\hline 10 & 2002 & 3 & 1 & 25 & 24.59 & 1.064 & 23.526 & 0.0001 & 0.0098 & 35 \\
\hline 10 & 2001 & 3 & 2 & 50 & 17.41 & 4.33 & 13.08 & & & 30 \\
\hline 10 & 2001 & 3 & 2 & 100 & 26.35 & 7.436 & 18.914 & & & 30 \\
\hline 10 & 2002 & 3 & 2 & 50 & 48.57 & 1.687 & 46.883 & 0.0001 & 0.0125 & 24 \\
\hline 10 & 2002 & 3 & 2 & 100 & 22.39 & 2.416 & 19.974 & 0.0561 & 0.0244 & 24 \\
\hline 10 & 2002 & 3 & 2 & 25 & 68.55 & 1.285 & 67.265 & 0.0652 & 0.0233 & 24 \\
\hline 10 & 2001 & 3 & 3 & 50 & 27.49 & 5.12 & 22.37 & & & 60 \\
\hline 10 & 2001 & 3 & 3 & 100 & 40.31 & 12.46 & 27.85 & & & 60 \\
\hline 10 & 2002 & 3 & 3 & 50 & 30.27 & 0.148 & 30.122 & 0.2456 & 0.0125 & 44 \\
\hline 10 & 2002 & 3 & 3 & 100 & 19.84 & 0.558 & 19.282 & 0.124 & 0.0086 & 44 \\
\hline 10 & 2002 & 3 & 3 & 25 & 51.88 & 1.54 & 50.34 & 0.0001 & 0.0001 & 44 \\
\hline 10 & 2001 & 3 & 4 & 50 & 13.99 & 0.324 & 13.666 & & & 50 \\
\hline 10 & 2001 & 3 & 4 & 100 & 26.51 & 2.358 & 24.152 & & & 50 \\
\hline 10 & 2002 & 3 & 4 & 50 & 38.41 & 1.659 & 36.751 & 0.0235 & 0.4411 & 38 \\
\hline 10 & 2002 & 3 & 4 & 100 & 30.26 & 0.248 & 30.012 & 0.5463 & 0.0218 & 38 \\
\hline 10 & 2002 & 3 & 4 & 25 & 68.49 & 2.555 & 65.935 & 0.776 & 0.0986 & 38 \\
\hline 10 & 2001 & 3 & 5 & 50 & 32.04 & 10.534 & 21.506 & & & 50 \\
\hline 10 & 2001 & 3 & 5 & 100 & 5.39 & 0.256 & 5.134 & & & 50 \\
\hline 10 & 2002 & 3 & 5 & 50 & 60.21 & 0.238 & 59.972 & 0.3265 & 0.0412 & 41 \\
\hline 10 & 2002 & 3 & 5 & 100 & 33.47 & 0.463 & 33.007 & 0.154 & 0.035 & 41 \\
\hline 10 & 2002 & 3 & 5 & 25 & 87.02 & 0.415 & 86.605 & 0.321 & 0.001 & 41 \\
\hline 10 & 2001 & 3 & 6 & 50 & 35.66 & 13.477 & 22.183 & & & 47 \\
\hline 10 & 2002 & 3 & 6 & 50 & 22.38 & 0.287 & 22.093 & 0.1 & 0.009 & 34 \\
\hline 10 & 2002 & 3 & 6 & 50 & 38.05 & 0.263 & 37.787 & 0.1251 & 0.0211 & 34 \\
\hline 10 & 2002 & 3 & 6 & 25 & 44.35 & 1.854 & 42.496 & 0.5462 & 0.009 & 34 \\
\hline 10 & 2001 & 3 & 6 & 100 & 21.6 & 1.388 & 20.212 & & & 47 \\
\hline
\end{tabular}




\section{APPENDIX 2: Vegetation Data}

Vegetation abbreviations in Table 4.

Percent cover of the overstory vegetation at the West Branch River Subwatershed study site.

\begin{tabular}{cccccccc} 
Transect & Station & OAR & O PB & O PM & O AI & O PG & O LL \\
\hline \hline 1 & 1 & 5 & 0 & 0 & 0 & 0 & 0 \\
1 & 2 & 0 & 100 & 0 & 0 & 0 & 0 \\
1 & 3 & 0 & 60 & 30 & 0 & 0 & 0 \\
1 & 4 & 0 & 10 & 5 & 0 & 0 & 0 \\
1 & 5 & 0 & 0 & 60 & 0 & 0 & 0 \\
1 & 6 & 0 & 0 & 60 & 0 & 0 & 0 \\
2 & 1 & 30 & 0 & 0 & 70 & 0 & 0 \\
2 & 2 & 0 & 0 & 0 & 10 & 25 & 0 \\
2 & 3 & 0 & 50 & 0 & 0 & 0 & 0 \\
2 & 4 & 0 & 60 & 0 & 0 & 0 & 0 \\
2 & 5 & 0 & 0 & 30 & 0 & 0 & 0 \\
2 & 6 & 0 & 0 & 30 & 0 & 0 & 0 \\
3 & 1 & 0 & 20 & 0 & 0 & 30 & 0 \\
3 & 2 & 0 & 20 & 0 & 0 & 30 & 0 \\
3 & 3 & 0 & 50 & 0 & 0 & 20 & 0 \\
3 & 4 & 0 & 50 & 0 & 0 & 0 & 0 \\
3 & 5 & 0 & 0 & 75 & 0 & 0 & 10 \\
3 & 6 & 0 & 0 & 50 & 0 & 0 & 0
\end{tabular}


Percent cover of the understory vegetation at the West Branch River Subwatershed study site.

\begin{tabular}{|c|c|c|c|c|c|c|c|c|c|c|c|c|c|c|c|c|c|}
\hline Transect & Station & U AR & U PM & U AI & U PG & U LL & UCF & U PS & U RH & U VA & U KP & U VC & U AM & U BP & $\mathrm{U}$ CHC & U LG & U D \\
\hline 1 & 1 & 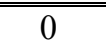 & 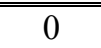 & 98 & 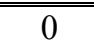 & 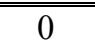 & 5 & 0 & 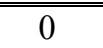 & 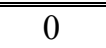 & 0 & 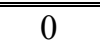 & 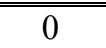 & 0 & 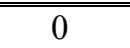 & 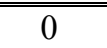 & 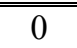 \\
\hline 1 & 2 & 0 & 0 & 17.5 & 10 & 0 & 0 & 10 & 0 & 0 & 0 & 0 & 0 & 0 & 0 & 0 & 0 \\
\hline 1 & 3 & 12.5 & 0 & 0 & 12.5 & 0 & 0 & 0 & 0 & 0 & 0 & 0 & 0 & 0 & 0 & 0 & 0 \\
\hline 1 & 4 & 0 & 0 & 0 & 0 & 0 & 0 & 0 & 5 & 30 & 0 & 0 & 0 & 0 & 0 & 0 & 0 \\
\hline 1 & 5 & 2.5 & 0 & 0 & 15 & 0 & 0 & 2.5 & 0 & 0 & 40 & 12.5 & 0 & 0 & 0 & 0 & 0 \\
\hline 1 & 6 & 0 & 12.5 & 0 & 0 & 0 & 0 & 0 & 0 & 15 & 0 & 2.5 & 0 & 0 & 0 & 7.5 & 0 \\
\hline 2 & 1 & 0 & 0 & 25 & 0 & 0 & 25 & 0 & 0 & 0 & 0 & 0 & 45 & 0 & 0 & 0 & 0 \\
\hline 2 & 2 & 0 & 0 & 35 & 0 & 0 & 0 & 0 & 0 & 0 & 0 & 0 & 0 & 25 & 0 & 0 & 0 \\
\hline 2 & 3 & 0 & 0 & 0 & 7.5 & 0 & 0 & 0 & 0 & 0 & 0 & 0 & 0 & 0 & 0 & 0 & 25.5 \\
\hline 2 & 4 & 0 & 0 & 0 & 5 & 0 & 0 & 2.5 & 0 & 0 & 0 & 15 & 0 & 0 & 10 & 20 & 0 \\
\hline 2 & 5 & 10 & 25 & 0 & 0 & 0 & 0 & 0 & 0 & 0 & 0 & 37.5 & 0 & 0 & 0 & 2.5 & 0 \\
\hline 2 & 6 & 7.5 & 5 & 0 & 0 & 0 & 0 & 0 & 0 & 0 & 0 & 25 & 0 & 0 & 0 & 40 & 0 \\
\hline 3 & 1 & 0 & 0 & 10 & 10 & 0 & 0 & 0 & 0 & 0 & 0 & 0 & 0 & 5 & 0 & 0 & 20 \\
\hline 3 & 2 & 0 & 0 & 10 & 10 & 0 & 0 & 0 & 0 & 0 & 0 & 0 & 0 & 5 & 0 & 0 & 20 \\
\hline 3 & 3 & 0 & 0 & 0 & 0 & 0 & 0 & 0 & 0 & 0 & 0 & 0 & 0 & 0 & 0 & 10 & 0 \\
\hline 3 & 4 & 0 & 0 & 0 & 5 & 10 & 0 & 0 & 15 & 0 & 0 & 0 & 5 & 0 & 0 & 2.5 & 0 \\
\hline 3 & 5 & 0 & 7.5 & 0 & 0 & 0 & 0 & 0 & 0 & 0 & 0 & 22.5 & 0 & 0 & 0 & 10 & 0 \\
\hline 3 & 6 & 5 & 25 & 0 & 0 & 0 & 0 & 0 & 0 & 0 & 0 & 15 & 0 & 0 & 0 & 17.5 & 0 \\
\hline
\end{tabular}


Percent cover of the non-bryophyte groundcover vegetation at the West Branch River Subwatershed study site.

\begin{tabular}{|c|c|c|c|c|c|c|c|c|c|c|c|c|c|c|c|}
\hline Transect & Station & G AI & G AM & G BP & $\mathrm{G} \mathrm{CC}$ & $\mathrm{G} \mathrm{CHC}$ & $\mathrm{G} \mathrm{C}$ & G CR & G CT & G COC & G DC & G D & G FV & G ER & G GB \\
\hline 1 & 1 & 16.67 & 46.66 & 3.33 & 0 & 0 & 0 & 0 & 0 & 0 & 0 & 0 & 0 & 0 & 6.67 \\
\hline 1 & 2 & 0 & 10 & 0 & 33.33 & 0 & 16.67 & 0 & 0 & 0 & 0 & 0 & 5 & 0 & 0 \\
\hline 1 & 3 & 0 & 0 & 0 & 0 & 0 & 10 & 0 & 5 & 15 & 0 & 10 & 0 & 0 & 0 \\
\hline 1 & 4 & 0 & 0 & 0 & 0 & 20 & 11.67 & 0 & 1.67 & 0 & 0 & 0 & 1.67 & 0 & 0 \\
\hline 1 & 5 & 0 & 0 & 0 & 0 & 3.33 & 0 & 0 & 6.67 & 8.33 & 0 & 0 & 0 & 1.67 & 0 \\
\hline 1 & 6 & 0 & 0 & 0 & 0 & 0 & 0 & 0 & 5 & 0 & 0 & 0 & 0 & 0 & 0 \\
\hline 2 & 1 & 0 & 0 & 0 & 1.67 & 0 & 0 & 0 & 0 & 0 & 0 & 0 & 0 & 0 & 26.67 \\
\hline 2 & 2 & 0 & 15 & 21.67 & 0 & 0 & 0 & 0 & 0 & 0 & 0 & 0 & 0 & 0 & 0 \\
\hline 2 & 3 & 0 & 0 & 0 & 0 & 0 & 0 & 0 & 0 & 0 & 15 & 5 & 0 & 0 & 0 \\
\hline 2 & 4 & 0 & 0 & 0 & 0 & 0 & 0 & 0 & 3.33 & 0 & 0 & 0 & 0 & 0 & 0 \\
\hline 2 & 5 & 0 & 0 & 0 & 0 & 0 & 0 & 0 & 5 & 1.67 & 0 & 0 & 0 & 0 & 0 \\
\hline 2 & 6 & 0 & 0 & 0 & 0 & 0 & 0 & 0 & 5 & 10 & 0 & 0 & 0 & 0 & 0 \\
\hline 3 & 1 & 0 & 0 & 0 & 20 & 0 & 0 & 0 & 0 & 20 & 0 & 0 & 16.67 & 0 & 0 \\
\hline 3 & 2 & 0 & 0 & 0 & 20 & 0 & 0 & 0 & 0 & 20 & 0 & 0 & 16.67 & 0 & 0 \\
\hline 3 & 3 & 0 & 0 & 0 & 0 & 0 & 0 & 1.67 & 3.33 & 0 & 0 & 0 & 15 & 0 & 0 \\
\hline 3 & 4 & 0 & 0 & 0 & 0 & 0 & 0 & 1.67 & 3.33 & 0 & 0 & 0 & 13.33 & 0 & 0 \\
\hline 3 & 5 & 0 & 0 & 0 & 0 & 0 & 0 & 0 & 40 & 10 & 0 & 0 & 0 & 0 & 0 \\
\hline 3 & 6 & 0 & 0 & 0 & 0 & 0 & 0 & 0 & 1.67 & 6.67 & 0 & 0 & 0 & 0 & 0 \\
\hline
\end{tabular}




\begin{tabular}{|c|c|c|c|c|c|c|c|c|c|c|c|c|c|c|c|}
\hline Transect & Station & G GH & G IV & G KP & G LG & $\mathrm{GMC}$ & $\mathrm{G} \mathrm{OS}$ & G P & G RH & G SU & G SP & G TD & G VA & G VC & G V \\
\hline 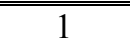 & $\bar{~} 1$ & $\overline{00}$ & 3.33 & $\overline{00}$ & $\overline{00}$ & 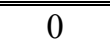 & $\overline{00}$ & $\overline{00}$ & 3.33 & $\overline{00}$ & $\overline{00}$ & 15 & $\overline{00}$ & $\overline{00}$ & 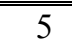 \\
\hline 1 & 2 & 0 & 11.67 & 0 & 0 & 6.67 & 0 & 0 & 5 & 0 & 0 & 0 & 0 & 0 & 5 \\
\hline 1 & 3 & 1.67 & 0 & 0 & 0 & 6.67 & 0 & 0 & 0 & 0 & 0 & 0 & 20 & 0 & 0 \\
\hline 1 & 4 & 0 & 13.33 & 6.67 & 0 & 3.33 & 0 & 0 & 0 & 0 & 0 & 0 & 0 & 0 & 0 \\
\hline 1 & 5 & 3.33 & 0 & 0 & 0 & 1.67 & 0 & 0 & 0 & 0 & 0 & 0 & 40 & 5 & 0 \\
\hline 1 & 6 & 3.33 & 0 & 0 & 3.33 & 1.67 & 0 & 0 & 0 & 0 & 0 & 0 & 6.67 & 0 & 0 \\
\hline 2 & 1 & 0 & 0 & 0 & 0 & 0 & 33.33 & 0 & 3.33 & 0 & 28.33 & 0 & 0 & 0 & 3.33 \\
\hline 2 & 2 & 0 & 0 & 0 & 0 & 0 & 0 & 0 & 0 & 33.33 & 0 & 0 & 0 & 0 & 10 \\
\hline 2 & 3 & 6.67 & 0 & 0 & 0 & 0 & 0 & 0 & 0 & 0 & 0 & 0 & 18.33 & 0 & 0 \\
\hline 2 & 4 & 0 & 0 & 0 & 0 & 3.33 & 0 & 0 & 3.33 & 0 & 0 & 0 & 16.67 & 0 & 0 \\
\hline 2 & 5 & 5 & 0 & 0 & 1.67 & 1.67 & 0 & 0 & 0 & 0 & 0 & 0 & 36.67 & 0 & 0 \\
\hline 2 & 6 & 10 & 0 & 3.33 & 0 & 1.67 & 0 & 0 & 0 & 0 & 0 & 0 & 16.67 & 0 & 0 \\
\hline 3 & 1 & 0 & 0 & 0 & 0 & 6.67 & 0 & 23.33 & 0 & 0 & 0 & 0 & 0 & 0 & 6.67 \\
\hline 3 & 2 & 0 & 0 & 0 & 0 & 6.67 & 0 & 23.33 & 0 & 0 & 0 & 0 & 0 & 0 & 6.67 \\
\hline 3 & 3 & 8.33 & 0 & 0 & 0 & 0 & 0 & 0 & 0 & 0 & 1.67 & 0 & 45 & 0 & 0 \\
\hline 3 & 4 & 0 & 0 & 0 & 0 & 0 & 0 & 0 & 0 & 0 & 0 & 0 & 43.33 & 0 & 0 \\
\hline 3 & 5 & 0 & 0 & 0 & 0 & 3.33 & 0 & 0 & 0 & 0 & 0 & 0 & 0 & 0 & 0 \\
\hline 3 & 6 & 0 & 0 & 0 & 0 & 0 & 0 & 0 & 0 & 0 & 0 & 0 & 8.33 & 0 & 0 \\
\hline
\end{tabular}


Percent cover of the Bryophyte and Sphagnum spp. groundcover vegetation at the West Branch River Subwatershed study site.

\begin{tabular}{cccccc} 
Transect & Station & B DI & B PL & B PO & B SP \\
\hline \hline 1 & 1 & 0 & 0 & 0 & 0 \\
1 & 2 & 0 & 0 & 0 & 0 \\
1 & 3 & 10 & 0 & 0 & 6.67 \\
1 & 4 & 10 & 0 & 0 & 31.67 \\
1 & 5 & 0 & 0 & 11.67 & 18.33 \\
1 & 6 & 0 & 0 & 0 & 58.33 \\
2 & 1 & 0 & 0 & 0 & 0 \\
2 & 2 & 0 & 0 & 0 & 0 \\
2 & 3 & 55 & 0 & 0 & 0 \\
2 & 4 & 63.33 & 0 & 0 & 10 \\
2 & 5 & 0 & 0 & 0 & 48.33 \\
2 & 6 & 0 & 0 & 0 & 58.33 \\
3 & 1 & 0 & 0 & 0 & 0 \\
3 & 2 & 0 & 0 & 0 & 0 \\
3 & 3 & 3.33 & 0 & 0 & 0 \\
3 & 4 & 41.67 & 0 & 0 & 0 \\
3 & 5 & 0 & 0 & 33.33 & 26.67 \\
3 & 6 & 0 & 5 & 26.67 & 75
\end{tabular}

